FEDERAL RESERVE BANK OF SAN FRANCISCO

WORKING PAPER SERIES

\title{
Optimal Capital Account Liberalization in China
}

\author{
Zheng Liu and Mark M. Spiegel \\ Federal Reserve Bank of San Francisco \\ Jingyi Zhang \\ Shanghai University \\ May 2020 \\ Working Paper 2018-10 \\ https://www.frbsf.org/economic-research/publications/working-papers/2018/10/
}

\section{Suggested citation:}

Liu, Zheng, Mark M. Spiegel, Jingyi Zhang. 2020. “Optimal Capital Account

Liberalization in China,” Federal Reserve Bank of San Francisco Working Paper 2018-

10. https://doi.org/10.24148/wp2018-10

The views in this paper are solely the responsibility of the authors and should not be interpreted as reflecting the views of the Federal Reserve Bank of San Francisco or the Board of Governors of the Federal Reserve System. This paper was produced under the auspices of the Center for Pacific Basin Studies within the Economic Research Department of the Federal Reserve Bank of San Francisco. 


\title{
OPTIMAL CAPITAL ACCOUNT LIBERALIZATION IN CHINA
}

\author{
ZHENG LIU, MARK M. SPIEGEL, AND JINGYI ZHANG
}

\begin{abstract}
China maintains tight controls over its capital account. Its current policy regime also features financial repression, under which banks are required to extend funds to state-owned enterprises (SOEs) at favorable terms, despite their lower productivity than private firms on average. We incorporate these features into a general equilibrium model. Our model illustrates a tradeoff between aggregate productivity and inter-temporal allocative efficiency from capital account liberalization under financial repression. As a result, along a transition path with a declining SOE share, welfare-maximizing policy calls for rapid removal of financial repression, but gradual liberalization of the capital account.
\end{abstract}

Date: May 27, 2020.

Key words and phrases. Capital controls, financial repression, China, sequencing of reforms, misallocations, welfare.

JEL classification: F38, G18, O41

Liu: Federal Reserve Bank of San Francisco; Email: Zheng.Liu@sf.frb.org. Spiegel: Federal Reserve Bank of San Francisco; Email: Mark.Spiegel@sf.frb.org. Zhang: School of Economics, Shanghai University of Finance and Economics, China; Email: zhang.jingyi@mail.shufe.edu.cn. We thank the Editor Urban Jermann and an anonymous referee for insightful comments that helped improve the paper. For helpful discussions, we thank Pierre-Olivier Gourinchas, Zhiguo He, Yi Huang, Jianjun Miao, Alessandro Rebucci, Thomas Sargent, Zheng Michael Song, Kjetil Storesletten, Pengfei Wang, Shang-Jin Wei, Wei Xiong, Vivian Yue, Tao Zha, Kai Zhao, Xiaodong Zhu, and conference and seminar participants at the FRBSF, the Bank of Finland, the 2018 China International Conference in Macroeconomics, the 2018 Reforms and Liberalization of China's Capital Market Conference, the IMF-FRB Atlanta China Workshop, and the inaugural Becker Friedman Institute-Tsinghua University joint conference on the Macroeconomy and Finance held in 2019 in Beijing, China. The research is supported by the National Natural Science Foundation of China Project Number 71633003. The views expressed in this paper are those of the authors and do not necessarily reflect the views of the Federal Reserve Bank of San Francisco or the Federal Reserve System. 


\section{INTRODUCTION}

China has maintained tight controls over its capital account. Domestic households are restricted from investing abroad and foreign investors are restricted from accessing Chinese financial markets. Most of the formal restrictions on capital flows are quantity-based. ${ }^{1}$ These de jure capital account restrictions, however, do not fully capture China's de facto capital account regime. For example, Agarwal et al. (2019) show that the errors and omissions $(\mathrm{E} \& \mathrm{O})$ in China's balance of payments account display a specific pattern suggesting that the intensity of government enforcement of capital account restrictions and private agents' efforts to circumvent such restrictions have resulted in a de facto capital account regime different from the de jure quantity-based capital flow restrictions. ${ }^{2}$

In recent years, the Chinese government has signaled its intention to liberalize the capital account, although the pace of liberalization remains uncertain. Some studies in the literature advocate gradual liberalization, arguing that rapid removals of capital account restrictions might disrupt domestic economic activity, particularly in a country with a distorted financial system. ${ }^{3}$

Financial distortions in China primarily take the form of financial repression, under which banks are encouraged to favor state-owned enterprises (SOEs) and other heavy-industry firms in their lending decisions, despite the lower average productivity

\footnotetext{
${ }^{1}$ For capital outflows, the Qualified Domestic Institutional Investor (QDII) program introduced in 2006 allows selected domestic financial institutions to trade in overseas-listed equities and debt securities subject to a quota that has remained small. An individual citizen is allowed to exchange up to $\$ 50,000$ of foreign currencies per year and any amount beyond that limit would require a permit from China's State Administration of Foreign Exchange (SAFE). For capital inflows, foreign direct investment (FDI) has been allowed and even encouraged, but its size has remained small, accounting for a bit under $2 \%$ of total fixed investment since 2015. Portfolio inflows are more restricted. Foreign investors can purchase B shares traded in Chinese stock markets, but the value of B shares has remained under 3\% of China's stock market capitalization since 2000 (Jeanne, 2013). Foreign financial institutions can also invest in Chinese equity and bond markets through the Qualified Foreign Institutional Investor (QFII) programs subject to a small quota, with a limited scope of investment assets (Lardy and Douglass, 2011).

${ }^{2}$ For example, during the period of 2000-2008, the Chinese government resisted capital inflows to mitigate the pressures on currency appreciation, and China's capital account exhibited positive net E\&O. Since late 2014, however, large depreciation pressures on the RMB started to intensify, and the government intervened to stem capital outflows, leading to large and positive E\&O in the balance of payments account.

${ }^{3}$ See, for example, Eichengreen et al. (2011), Eichengreen and Leblang (2003), Chinn and Ito (2006), Ju and Wei (2010), and Aoki et al. (2009). See also Wei (2018) for a survey.
} 
of SOEs than private firms (or privately owned enterprises, henceforth "POEs"). ${ }^{4}$ As a result, POEs often have to pay higher interest rates on their loans than do SOEs. Given these distortions, it is possible that capital account liberalization may exacerbate resource misallocation. However, as discussed in Wei (2018), "there is a lack of formal theories that articulate this link."

In this paper, we present a theoretical framework to evaluate the general equilibrium effects of capital account liberalization policies under China's distorted financial system. We build a small open economy model with overlapping generations, featuring financial repression and capital controls, similar to the prevailing policy regime in China. Households live for two periods - young and old. When they are young, they work, consume, and accumulate assets; when they are old, they retire and consume savings. To save, a young household can make deposits in domestic banks or purchase foreign bonds. Households consume a final consumption good produced using a composite of intermediate inputs supplied by SOEs and POEs. In each sector, firms use capital and labor as inputs for production and borrow from banks or foreign investors to finance working capital. Consistent with empirical evidence, we assume that SOEs have lower productivity on average than POEs (Hsieh and Klenow, 2009).

Our model captures China's de facto capital account restrictions, which do not necessarily coincide with the quantity-based de jure capital account polices. In particular, we model China's capital account policy in a reduced form as capital flow taxes that can be potentially time-varying. The government restricts capital outflows by imposing a tax on foreign asset earnings. This capital outflow restriction drives a wedge between domestic deposit interest rates and the world interest rate. The government also restricts capital inflows by imposing a tax on repatriated earnings to foreign investors. In addition, foreign debt requires a risk premium, which increases with the size of the debt. The capital inflow restrictions and the risk premium drive a wedge between domestic lending rates and the world interest rate. ${ }^{5}$

\footnotetext{
${ }^{4}$ While some heavy industry firms are not state-owned, Chang et al. (2016) find that the share of SOEs in capital-intensive industries has increased steadily since the late 1990s reforms. In practice, large private firms have little difficulty obtaining funds from China's commercial banks, but the primary funding sources for those firms are the the bond and equity markets. This leaves SOEs the primary beneficiaries of China's financial repression. Throughout the paper, we use the term "SOE" as representative of all sectors or industries that receive favorable credit treatments.

${ }^{5}$ The dependence of the risk premium on the size of the external debt can be interpreted as an upward-sloping supply curve of foreign funds stemming from sovereign risk or costs of portfolio adjustment. Since individual firms do not internalize the effects of their borrowing levels on the
} 
Financial repression takes the form of directed lending. Banks are required to extend a fraction of their loans to SOEs at below-market interest rates. In contrast, POEs borrow only at market rates. SOEs have the option to borrow beyond the level dictated by directed lending, but they pay market rates on additional borrowing. We assume that the interest rate on directed loans is lower than the deposit rate. Thus, directed lending is unprofitable, and banks can remain solvent only with sufficiently low interest rates on household deposits and high market interest rates. Financial repression therefore drives a wedge between domestic deposit rates and market lending rates. ${ }^{6}$

These distortions lead to resource misallocations, both across sectors and across time. Subsidized bank loans to SOEs, combined with restricted POE access to prevailing global borrowing opportunities, encourage SOE activity at the expense of POEs. Since POEs are more productive, this misallocation depresses aggregate productivity. At the same time, bank losses from directed lending to SOEs depress domestic deposit rates, boosting the households' incentive to move their savings abroad. However, taxes on capital outflows discourage them from doing so, distorting domestic consumption-savings decisions.

Using this framework, we examine the implications of capital account liberalization in the presence of financial repression. Our analysis - based on analytical solutions and calibrated numerical simulations - highlights the tradeoff between aggregate productivity and intertemporal allocative efficiency, both in the steady state and along a transition path.

The analytical steady-state solution of our model demonstrates an interior optimum for capital account restrictions on both inflows and outflows. For example, consider a permanent relaxation of outflow controls, holding inflow controls constant. Cutting outflow taxes enables households to obtain higher earnings on their savings and thus mitigates distortions to their consumption-savings decisions. However, domestic banks

risk premium, our decentralized equilibrium features an over-borrowing externality similar to that studied by Bianchi (2011).

${ }^{6}$ Explicit directed lending is not as prevalent today in China as it was at the turn of the century, but analogous policy distortions favoring protected sectors remain prevalent [e.g. Chen et al. (2017)] Our simple, stylized approach to modeling financial repression enables us to obtain analytical characterizations of the steady-state equilibrium, which help better understand the model's mechanism. The main results, however, do not hinge upon this particular approach to modeling financial repression. We have obtained qualitatively similar results when we consider an alternative and arguably more realistic model of financial repression that stems from the government's bailout guarantees on SOE loans, as we discuss in Section VIII. 
face increased funding costs and respond by raising market lending rates. Thus, the relative funding costs for POEs rise and resources are shifted to less productive SOEs. This process exacerbates the misallocation across sectors and reduces aggregate productivity.

Alternatively, consider a liberalization of capital inflows, keeping outflow controls unchanged. A lower tax on capital inflows enhances POE access to foreign funding, and thus raises relative POE output and aggregate productivity. However, the increase in foreign capital inflows reduces the domestic market lending rate. Given bank losses on directed lending, the reduction in the market lending rate requires a reduction in deposit rates to maintain bank solvency. The decline in the deposit rate exacerbates the distortions on the households' consumption-savings decisions. ${ }^{7}$

For liberalizations of both inflow and outflow controls, optimal capital flow tax rates depend on the severity of financial repression. More severe financial repression calls for stricter controls over both inflows and outflows. When the planner can optimize the degree of financial repression as well, welfare is maximized by eliminating both financial repression and capital controls in the steady-state equilibrium. ${ }^{8}$

Our model also illustrates a tradeoff between aggregate productivity and intertemporal allocative efficiency for optimal liberalization policies along the transition path of structural changes. We consider a permanent decline in the expenditure share of SOE goods, as observed in the Chinese data. We examine the welfare implications of alternative paces and depths of liberalizing the capital account and financial repression, taking into account the transition dynamics.

Optimal policy under transition calls for gradual capital account liberalization and a relatively fast pace of financial reforms. As in the steady state, given financial repression, a tradeoff exists under transition in liberalizing controls over either inflows or outflows. In particular, while relaxing outflow controls alone benefits households by raising domestic deposit rates, it also raises POE funding costs, and thus reduces

\footnotetext{
${ }^{7}$ The benefits of relaxing capital inflow controls are also partly offset by the over-borrowing externality associated with the risk premium on foreign debt.

${ }^{8}$ There may be other reasons why the government wants to protect SOEs or heavy industries. One possibility is monopolistic competition in the SOE sector, which we modeled in an earlier version of the paper. Given monopolistic competition, SOE production without subsidized lending would be inefficiently low. Alternatively, the government may want to subsidize SOEs because SOEs are expected to maintain employment or to provide some public goods (Brandt and Zhu, 2000). Modeling these alternative considerations would be beyond the scope of our paper.
} 
aggregate productivity by reallocating resources to less productive SOEs. Alternatively, while relaxing inflow controls alone reduces POE funding costs and improves aggregate productivity, the increased competition from foreign investors pushes down domestic lending rates and forces banks to cut domestic deposit rates, further distorting households' intertemporal consumption-savings decisions. In addition, the increased foreign debt also raises the risk premium, exacerbating the over-borrowing externality. In the more general case where the planner can liberalize both financial repression and capital controls, optimal policy calls for a rapid removal of financial distortions, but more gradual and moderate liberalization of the capital account.

Our model's prediction that an increase in capital inflows should lead to a contraction in the relative activity of SOEs is broadly in line with the impulse responses estimated in a Bayesian VAR (BVAR) model. Figure 1 shows the impulse responses following a positive shock to capital inflows. The BVAR includes four variables: the ratio of capital inflows to GDP, the ratio of private capital outflows to GDP, the ratio of new bank loans to GDP, and the share of SOE investment in aggregate investment, in that order. Under this Cholesky identification assumption, capital outflows, bank loans, and the SOE investment share are all allowed to respond to shocks to capital inflows on impact, whereas the capital inflow measure does not respond to the other shocks in the impact period. ${ }^{9}$ Consistent with the model, a shock that raises capital inflows also raises capital outflows, reduces new bank loans, and lowers the SOE investment share.

However, our model has ambiguous predictions for the impact of an increase in capital outflows on relative SOE activity. An increase in capital outflows raises domestic market interest rates and depresses relative POE activity. At the same time, an increase in outflows also reduces total domestic bank loans that are available for firms in both the SOE and POE sectors, leaving the overall effects on relative SOE investment ambiguous, since SOEs disproportionately benefit from increased overall bank lending under financial repression. Figure 2 confirms this intuition with a BVAR model, which includes the same four variables as above, but with the capital outflows ordered first. Consistent with our model's predictions, a shock that raises capital outflows also raises capital inflows, and it leads to a significant decline in new bank loans, but with a small and insignificant decline in the SOE investment share.

\footnotetext{
${ }^{9}$ We use quarterly data from 1998:Q1 to 2016:Q4. The series of SOE investment, aggregate fixed investment, new bank loans, and real GDP are taken from Chang et al. (2016). The series of capital inflows and outflows are from China's State Administration Of Foreign Exchange (SAFE).
} 


\section{RELATED LiterATURE}

Our paper contributes to the large literature on capital account distortions. Capital account restrictions can distort domestic financial markets (Edwards, 1999; Jeanne et al., 2012). They can also distort international trade, effectively mimicking an increase in tariffs (Wei and Zhang, 2007; Costinot et al., 2014) or a devaluation of the real exchange rate (Jeanne, 2013). ${ }^{10}$ Chang et al. (2015) demonstrate that sterilized intervention required in China to maintain its closed capital account policy was costly and constrained domestic monetary policy. ${ }^{11}$ Temporary capital account restrictions can help stabilize large fluctuations in capital inflows (Ostry et al., 2010). However, the welfare effects of such capital flow taxes depend on whether or not policy commitment is available (Devereux et al., 2019). Properly designed, temporary capital account policies can serve as a useful tool to mitigate the effects of external shocks (Farhi and Werning, 2012; Unsal, 2013; Davis and Presno, 2017).

Some studies are skeptical about the merits of capital account liberalization under financial distortions. For example, Eichengreen et al. (2011) demonstrate that capital account liberalization can adversely impact countries with poorly-developed financial markets. Eichengreen and Leblang (2003) argue that, for a country with a distorted financial system that is conducive to excessive risk taking, opening the capital account may further increase leverage and thus raise the likelihood of a financial crisis. Chinn and Ito (2006) argue that capital account liberalization can be detrimental in countries with insufficiently developed institutions. Ju and Wei (2010) show that capital account liberalization can improve welfare in advanced financial systems, but can have ambiguous effects under poorly-developed financial systems. Similarly, Aoki et al. (2009) demonstrate that, with poorly-developed financial systems, capital account liberalization can potentially lead to welfare-reducing long-run stagnation or short-run drops in employment. Those who do advocate for relaxing capital account restrictions often rely on arguments based on potential "secondary improvements" or "discipline effects" for domestic institutions stemming from exposures to foreign competition and standards (Kose et al., 2009; Wei and Tytell, 2004).

Given the ambivalence about the welfare implications of capital account liberalization in the literature, some have argued that China should undertake domestic

\footnotetext{
${ }^{10}$ However, evidence that capital controls themselves inhibit growth is limited (e.g. Jeanne (2013)).

${ }^{11}$ However, by limiting the pressure for capital inflows, capital account restrictions can themselves ease the need for undertaking such costly sterilization activity (Liu and Spiegel, 2015).
} 
financial reforms prior to liberalizing its capital account [e.g. (Hsu, 2016)]. ${ }^{12}$ Our analysis below provides a theoretical framework that formally illustrates the tradeoffs incurred by capital account liberalization under financial repression.

Our work is related to Song et al. (2014), who study an overlapping generations model with capital controls. They take capital controls as given and examine the implications of several domestic financial liberalization policies. Our model features two-way capital flows, as in Wang et al. (2015), who derive a model in which financial distortions in China result in excessive savings by households and high rates of domestic returns on capital, leading to two-way capital flows in equilibrium. However, these papers do not study the implications of capital account liberalization, which is the focus of our paper.

Our work is also related to the literature on misallocations under financial frictions in China. A prominent example is the work of Song et al. (2011), who examine China's transition dynamics in a two-period overlapping generations model in which less productive SOEs have easier access to credit than POEs. Their model's transition dynamics explain some puzzling characteristics of the Chinese economy, such as high growth being accompanied by high saving rates. Chang et al. (2019) examine the macroeconomic effects of changes in reserve requirements in a two-sector model of China with an infinite horizon and financial frictions. In their model, SOEs have access to government-guaranteed on-balance sheet loans at lower interest rates, while POEs obtain funding only from off-balance sheet sources with a higher credit spread. Increases in reserve requirements act like a tax on SOE activity, reallocating resources to productive POEs and raising aggregate productivity. Liu et al. (2020) study the consequences of interest-rate liberalization in China in a two-sector closed-economy model, in which SOEs are less efficient than POEs but enjoy easier access to credit and production subsidies from the government. Interest-rate liberalization in their model improves resource allocations within each sector, but exacerbates misallocations across sectors.

Related to this literature, we also study misallocations between SOEs and POEs. We consider an open-economy environment in which potential misallocations can stem from interactions between capital account restrictions and domestic financial market distortions. Our model highlights a novel tradeoff associated with capital account

\footnotetext{
${ }^{12}$ Similar arguments were made much earlier concerning the proper order of liberalizing the current and capital accounts of an emerging market economy. For example, see Edwards (1984).
} 
liberalization under financial repression: a tradeoff between intertemporal allocative efficiency and production efficiency.

\section{The MOdeL}

We consider a small open economy model with overlapping generations. There is a continuum of households, each living for two periods-young and old. When young, the household works, consumes, and saves for retirement. When old, the household consumes the accumulated savings. The final consumption good is a composite of intermediate goods produced by competitive firms in two sectors - one sector with state-owned enterprises (SOEs) and the other sector with private firms (POEs).

Consistent with empirical evidence, SOEs have lower average productivity than POEs. Firms in both sectors rely on bank loans to finance wage and rental payments and they face working capital constraints.

Banks operate in a perfectly competitive market, taking as given interest rates on deposits and lending. The government provides favorable credit treatment to SOEs by directing banks to lend a minimum share of their available funds to SOEs at belowmarket interest rates. Banks lend their remaining funds at market interest rates to SOEs or POEs. Under its capital control policy regime, the government imposes taxes on both capital inflows and outflows.

III.1. The households. Each household lives for two periods, young in the first period and old in the second. Young households work for firms and receive labor income. They consume a part of their labor income and save the rest for retirement. Old households are retired and consume their accumulated savings.

A representative household born in period $t$ has the utility function

$$
\max \mathrm{E}\left\{\ln \left(C_{t}^{y}\right)-\Psi_{h} \frac{H_{t}^{1+\eta}}{1+\eta}+\beta \ln \left(C_{t+1}^{o}\right)\right\},
$$

where $C_{t}^{y}$ denotes consumption of the household when young, $C_{t+1}^{o}$ denotes consumption when old, and $H_{t}$ denotes hours worked when young.

The household chooses consumption, savings in domestic and foreign banks, and capital investment to maximize the utility function (1) subject to the budget constraints

$$
C_{t}^{y}+D_{t}+B_{f t}^{d}+q_{t}^{k} K_{t}^{o}+I_{t}+\frac{\Omega_{k}}{2}\left(\frac{I_{t}}{K_{t}^{o}}-\frac{\bar{I}}{\bar{K}^{o}}\right)^{2} K_{t}^{o}=w_{t} H_{t}+T_{t}+\Gamma_{t},
$$

and

$$
C_{t+1}^{o}=R_{t} D_{t}+\left(1-\tau_{d}\right) R_{t}^{*} B_{f t}^{d}+d_{t+1}+\left[q_{t+1}^{k}(1-\delta)+r_{t+1}^{k}\right]\left(K_{t}^{o}+I_{t}\right)-\Gamma_{t+1}
$$


When young, the household consumes $C_{t}^{y}$, saves $D_{t}$ in domestic banks and $B_{f t}^{d}$ in foreign banks, purchases existing capital $K_{t}^{o}$ from the then old generation at the price $q_{t}^{k}$, and makes new investment subject to the quadratic adjustment cost, with the scale of adjustment cost determined by the parameter $\Omega_{k}$. The young household finances these expenditures with the wage income $w_{t} H_{t}$, the lump-sum transfer $T_{t}$ from the government, and the bequest $\Gamma_{t}$ from the previous old generation. ${ }^{13}$ The bequest is a constant fraction $\Gamma$ of the wealth held by the old and it is given by

$$
\Gamma_{t}=\Gamma\left\{R_{t-1} D_{t-1}+\left(1-\tau_{d}\right) R_{t-1}^{*} B_{f, t-1}^{d}+d_{t}+\left[q_{t}^{k}(1-\delta)+r_{t}^{k}\right]\left(K_{t-1}^{o}+I_{t-1}\right)\right\} .
$$

When old, the household consumes the asset holdings, consisting of interest earnings on domestic deposits $R_{t} D_{t}$, after-tax earnings on foreign investment $\left(1-\tau_{d}\right) R_{t}^{*} B_{f t}$, dividend income $d_{t+1}$ from firms that the household owns, and the gross returns from capital investment consisting of the resale value of capital net of depreciation at the rate $\delta$ and the flow capital income at the rental rate $r_{t+1}^{k}$. The old household also leaves bequests $\Gamma_{t+1}$ to the then-young generation.

The household's optimizing decisions with respect to domestic and foreign bonds imply the no arbitrage condition

$$
R_{t}=\left(1-\tau_{d}\right) R_{t}^{*}
$$

A positive tax rate $\tau_{d}$ captures capital outflow controls. Thus, capital outflow controls drive a wedge between the domestic deposit rate and the world interest rate. ${ }^{14}$

The aggregate stock of physical capital $K_{t}$ available at the end of period $t$ consists of existing capital owned by the old $K_{t}^{o}=(1-\delta) K_{t-1}$ and new investment by the young $I_{t}$. Thus, the capital stock evolves according to the law of motion

$$
K_{t}=(1-\delta) K_{t-1}+I_{t}
$$

III.2. The final goods sector. Final goods are produced using intermediate goods supplied from the two sectors: SOE and POE. The production function is given by

$$
Y_{t}=\left(\phi_{t} Y_{s t}^{\frac{\sigma_{m}-1}{\sigma_{m}}}+\left(1-\phi_{t}\right) Y_{p t}^{\frac{\sigma_{m}-1}{\sigma_{m}}}\right)^{\frac{\sigma_{m}}{\sigma_{m}-1}}
$$

\footnotetext{
${ }^{13}$ The results are invariant if the lump-sum transfers were made to the old.

${ }^{14}$ In our benchmark model, we focus on an interior solution with positive capital outflows, so that the no-arbitrage condition (5) holds. In examining the impact of capital account liberalization, we also consider counterfactuals in which $\tau_{d}$ takes a wide range of values. We show that, if $\tau_{d}$ is sufficiently high, then there would be no capital outflows in equilibrium, and Eq. (5) would be replaced by the condition that $B_{f t}^{d}=0$.
} 
where $Y_{t}$ denotes the final good output, $Y_{s t}$ and $Y_{p t}$ denote the intermediate input produced in the SOE sector and POE sector, respectively, $\sigma_{m}$ represents the elasticity of substitution between intermediate goods produced by the two sectors, and the term $\phi_{t} \in(0,1)$ measures the expenditure share of SOE goods used in final goods production. ${ }^{15}$ We allow the SOE share to be time varying to study the implications of capital account liberalization under structural changes. We focus the structural change associated with gradual declines in the SOE share observed in China over recent decades.

Denote by $p_{s t}$ and $p_{p t}$ the relative price of SOE products and POE products, respectively, both expressed in final consumption good units. Cost-minimizing by the final good producer implies that

$$
Y_{s t}=p_{s t}^{-\sigma_{m}} \phi_{t}^{\sigma_{m}} Y_{t}, \quad Y_{p t}=\left(1-\phi_{t}\right)^{\sigma_{m}} p_{p t}^{-\sigma_{m}} Y_{t}
$$

The zero-profit condition in the final good sector implies that

$$
1=\phi_{t}^{\sigma_{m}} p_{s t}^{1-\sigma_{m}}+\left(1-\phi_{t}\right)^{\sigma_{m}} p_{p t}^{1-\sigma_{m}}
$$

III.3. Intermediate goods sectors. Intermediate goods are produced in both the SOE sector and the POE sector. We focus on describing the optimizing decisions of a representative firm in each sector $j \in\{s, p\}$, where $s$ denotes the SOE sector and $p$ denotes the POE sector.

A firm in sector $j$ produces a homogeneous intermediate good $Y_{j t}$ using capital $K_{j t}$ and labor $H_{j t}$ as inputs, with the production function

$$
Y_{j t}=A_{j}\left(K_{j t}\right)^{1-\alpha}\left(H_{j t}\right)^{\alpha}
$$

where $A_{j}$ denotes a sector-specific productivity facing all firms in sector $j$, and the parameter $\alpha \in(0,1)$ is the labor input elasticity in the production function.

Firms in both sectors face competitive input markets and product markets. Each firm also faces working capital constraints. Before production takes place, a firm needs to pay wages and capital rents with working capital loans $B_{j t}$ obtained from banks, at the interest rate $R_{j t}$. The firm repays the loans at the end of the period

\footnotetext{
${ }^{15}$ The CES aggregate technology between SOE goods and POE goods follows from Chang et al. (2016). We calibrate the elasticity parameter $\sigma_{m}$ based on the empirical estimates obtained by Chang et al. (2016) using Chinese data. Our results are robust when we consider alternative values of the elasticity parameter. We provide the details of this robustness analysis in an online appendix at https://www.frbsf.org/economic-research/files/wp2018-10_appendix.pdf.
} 
when production is completed. The working capital constraint for a firm in sector $j \in\{s, p\}$ is given by

$$
B_{j t}=w_{t} H_{j t}+r_{t}^{k} K_{j t}
$$

Cost-minimizing implies that

$$
w_{t} H_{j t} R_{j t}=\alpha Y_{j t} p_{j t}
$$

and

$$
r_{t}^{k} K_{j t} R_{j t}=(1-\alpha) Y_{j t} p_{j t}
$$

Under perfect competition, constant returns production technologies and free entry imply that all firms earn zero economic profit.

III.4. Banks. There is a continuum of competitive banks. The representative bank takes deposits $D_{t}$ from households at the deposit interest rate $R_{t}$ and lends to firms in the SOE and POE sectors, with the amount $B_{s t}^{d}$ and $B_{p t}^{d}$, respectively. The flow of funds constraint of the bank is then given by,

$$
D_{t} \geq B_{s t}^{d}+B_{p t}^{d}
$$

To capture financial repression in China, we assume that the government requires the bank to lend a minimum fraction of its loanable funds, $\gamma \in[0,1)$, to SOEs at a below-market interest rate, which we normalize to zero. The bank lends its remaining funds to domestic firms at the market loan rate $R_{l t}$.

Denote by $B_{g t}$ the amount of directed lending to SOEs. The directed lending policy implies that

$$
B_{g t} \geq \min \left\{\gamma\left(B_{s t}^{d}+B_{p t}^{d}\right), B_{s t}^{d}\right\} .
$$

The parameter $\gamma$ measures the severity of financial repression. Under the directed lending policy in Eq. (15), SOEs can borrow at the subsidized interest rate for up to a fraction $\gamma$ of the total bank loans.

The representative bank maximizes its profits

$$
B_{g t}+R_{l t}\left(B_{s t}^{d}+B_{p t}^{d}-B_{g t}\right)-R_{t} D_{t}
$$

subject to the constraint (15) and the flow of funds constraint (14).

Since banks are risk neutral and there is free entry, the representative bank earns zero profits in equilibrium. The zero-profit condition implies that

$$
R_{t}=\frac{B_{g t}}{B_{s t}^{d}+B_{p t}^{d}}+\left(1-\frac{B_{g t}}{B_{s t}^{d}+B_{p t}^{d}}\right) R_{l t} .
$$


Thus, $R_{l t}>R_{t}$ if and only if $B_{g t}>0$, which holds under financial repression. Financial repression drives a wedge between the loan rate and the deposit rate, since the bank must charge an interest rate $R_{l t}$ on market lending that exceeds the deposit interest rate $R_{t}$ to break even.

III.5. Foreign investors. Foreign investors can lend to domestic firms at the market loan rate $R_{l t} .{ }^{16}$ The Chinese government restricts capital inflows by taxing repatriated earnings for foreign investors at the rate $\tau_{l}$. Thus, the after-tax return received by foreign investors on their investment to Chinese firms is given by $\left(1-\tau_{l}\right) R_{l t}$.

External borrowing is subject to a risk premium, $\Phi\left(\frac{B_{f t}^{l}}{Y_{t}}\right)$, which is an increasing function of the ratio of external debt $\left(B_{f t}^{l}\right)$ to aggregate output $\left(Y_{t}\right)$. In our benchmark model, we focus the equilibrium with a positive capital inflows, so that ${ }^{17}$

$$
\left(1-\tau_{l}\right) R_{l t}=R_{t}^{*} \Phi\left(\frac{B_{f t}^{l}}{Y_{t}}\right) .
$$

The dependence of the risk premium on the relative size of external debts generates a spillover externality that leads to over-borrowing, as individual firms take the loan interest rate as given. The presence of the capital inflow tax and the risk premium drives a wedge between domestic loan interest rate and the world interest rate.

III.6. Market clearing and equilibrium. An equilibrium consists of sequences of allocations $\left\{C_{t}^{y}, C_{t}^{o}, I_{t}, K_{t}^{o}, Y_{t}, K_{s t}, K_{p t}, H_{s t}, H_{p t}, K_{t}, H_{t}, B_{s t}, B_{p t}, B_{g t}, B_{t}, B_{f t}^{l}, N X_{t}\right\}$ and prices $\left\{w_{t}, R_{t}, q_{t}^{k}, r_{t}^{k}, p_{s t}, p_{p t}, R_{s t}, R_{p t}, R_{l t}\right\}$ that solve the optimizing problems for the households, the firms, and the banks. In the equilibrium, the markets for the loanable funds, capital, labor, and goods all clear.

The loan market clearing condition is given by ${ }^{18}$

$$
B_{s t}=B_{s t}^{d}, \quad B_{p t}=B_{p t}^{d}+B_{f t}^{l} .
$$

\footnotetext{
${ }^{16}$ In principle, foreign investors could also access China's financial market by depositing funds at Chinese banks. However, given capital outflow controls, the deposit interest rate lies below the world interest rate (see Eq. (5)). Thus, in an equilibrium, foreign investors choose not to lend to Chinese banks.

${ }^{17}$ In our counterfactual analysis, we consider a wide range of values of $\tau_{l}$. We show that, for sufficiently high values of $\tau_{l}$, there would be no capital inflows and the no-arbitrage condition (18) would be replaced by $B_{f t}^{l}=0$.

${ }^{18}$ The model assumes that an SOE is entitled to $\frac{B_{g t}}{B_{s t}^{d}}$ units of directed loans for each unit of funds it borrows from domestic banks. To maximize their access to directed loans at the subsidized interest rate, SOEs do not borrow from foreign investors.
} 
Capital and labor are both perfectly mobile across sectors, so that the labor market and the capital market clearing implies that

$$
H_{t}=H_{s t}+H_{p t}, \quad K_{t-1}=K_{s t}+K_{p t}
$$

Final goods market clearing implies that the trade surplus (or net exports, denoted by $N X_{t}$ ) is given by

$$
N X_{t}=Y_{t}-C_{t}^{y}-C_{t}^{o}-I_{t}-\frac{\Omega_{k}}{2}\left(\frac{I_{t}}{K_{t}^{o}}-\frac{\bar{I}}{\bar{K}^{o}}\right)^{2} K_{t}^{o} .
$$

By summing up all sectors' budget constraints, we obtain the balance of payments equation

$N X_{t}+\left(R_{t-1}^{*}-1\right) B_{f, t-1}^{d}-\left[R_{t-1}^{*} \Phi\left(\frac{B_{f, t-1}^{l}}{Y_{t-1}}\right)-1\right] B_{f, t-1}^{l}=\left(B_{f t}^{d}-B_{f t}^{l}\right)-\left(B_{f, t-1}^{d}-B_{f, t-1}^{l}\right)+\Delta_{t}$.

The left-hand side of the equation is the current account balance, consisting of net exports and net interest income from abroad. The right-hand side is the (negative of the) financial account balance, measuring changes in net capital inflows. ${ }^{19}$ In equilibrium, the current account and the financial account sum up to zero.

\section{Steady-STAte Misallocations Under POLICY Distortions: SOME}

\section{ANALYTICAL RESULTS}

This section provides some analytical characterizations of the implications of capital controls and directed lending for steady-state resource allocations and aggregate productivity. We present the main analytical results here and relegate details of the derivations and some proofs to Appendix A.

To keep the analytics tractable, we consider the Cobb-Douglas production function for the final goods sector

$$
Y=Y_{s}^{\phi} Y_{p}^{1-\phi}
$$

where $\phi$ is the expenditure share of SOE goods. This is a special case of the CES aggregation technology Eq. (7) with $\sigma_{m}=1$. The cost-minimizing solution (8) for the final goods producer becomes

$$
Y_{s} p_{s}=\phi Y, \quad Y_{p} p_{p}=(1-\phi) Y
$$

\footnotetext{
${ }^{19}$ The last term $\Delta_{t} \equiv R_{s t} B_{s t}+R_{p t} B_{p t}-R_{s, t-1} B_{s, t-1}-R_{p, t-1} B_{p, t-1}$ emerges from our model's timing assumption: banks receive repayments on their working capital loans at the end of period $t$, whereas they repay deposits to the households at the beginning of period $t+1$.
} 
We assume that the risk-premium function takes the form

$$
\Phi\left(\frac{B_{f t}^{l}}{Y_{t}}\right)=\exp \left[\Phi_{b}\left(\frac{B_{f t}^{l}}{Y_{t}}-\kappa_{f}\right)\right],
$$

where the parameter $\Phi_{b}$ measures the elasticity of the risk premium to the ratio of external debts to output and the term $\kappa_{f}$ is a constant. Given this functional form of the risk premium, the no-arbitrage condition (18) implies that the ratio of foreign capital inflows to output is given by

$$
b_{f} \equiv \frac{B_{f t}^{l}}{Y_{t}}=\kappa_{f}+\frac{1}{\Phi_{b}} \ln \left[\frac{\left(1-\tau_{l}\right) R_{l}}{R^{*}}\right] .
$$

We examine the steady-state implications of capital controls and financial repression for resource allocations between the SOE sector and the POE sector and also for aggregate productivity. We focus on the interior equilibrium with positive gross capital flows (both inflows and outflows) and positive domestic bank loans (including both market loans and directed loans). Denote by $S\left(\tau_{d}, \tau_{l}, \gamma\right) \equiv \frac{K_{s}}{K_{p}}$ the ratio of capital used by the SOE sector to that by the POE sector, which is a function of the policy parameters $\tau_{d}, \tau_{l}$, and $\gamma$.

The cost-minimizing solutions (12) and (13) for the intermediate goods producing firms imply that the labor input ratio across sectors is identical to the capital input ratio (i.e., $\frac{H_{s}}{H_{p}}=\frac{K_{s}}{K_{p}}=S\left(\tau_{d}, \tau_{l}, \gamma\right)$.) Thus, we focus on $S\left(\tau_{d}, \tau_{l}, \gamma\right)$ as a measure for resource allocations across the sectors.

Using the cost-minimizing solution for the final goods sector in Eq. (24) and those for the intermediate goods sectors in Eq. (12) and (13), we obtain

$$
S\left(\tau_{d}, \tau_{l}, \gamma\right)=\frac{K_{s}}{K_{p}}=\frac{R_{p}}{R_{s}} \frac{\phi}{1-\phi}
$$

The funding cost for POEs is just the market loan rate, so that $R_{p}=R_{l}$, which is in turn related to the deposit interest rate $R$ through the banks' break-even condition (17), so that $R_{l}=\frac{R-\gamma}{1-\gamma} \cdot{ }^{20}$ In the interior equilibrium, we have

$$
R=\left(1-\tau_{d}\right) R^{*}, \quad R_{l}=\frac{\left(1-\tau_{d}\right) R^{*}-\gamma}{1-\gamma}
$$

These relations imply that tightening of capital outflow controls (increasing $\tau_{d}$ ) depresses domestic interest rates, while increasing financial repression (raising $\gamma$ ) widens the wedge between the lending rate and the deposit rate.

\footnotetext{
${ }^{20}$ In the interior equilibrium with positive market loans to SOEs $\left(B_{s t}-B_{g t}>0\right)$, Eq. (17) implies that $B_{g t}=\gamma\left(B_{s t}^{d}+B_{p t}^{d}\right)$.
} 
An SOE firm has access to directed lending, $B_{g}$, as well as the option to borrow at the market interest rate if its working capital demand exceeds the amount of directed loans. Thus, the effective funding cost for SOEs $\left(R_{s}\right)$ is given by

$$
R_{s}=\frac{B_{g}+R_{l}\left(B_{s}-B_{g}\right)}{B_{s}}
$$

where $B_{s}$ is the total amount of SOE loans, consisting of both the directed lending, $B_{g}$, at zero interest and market loans, $B_{s}-B_{g}$, at the market loan rate.

As we show in Appendix A, the relative size of the SOE sector, measured by the share of capital (or labor) used by SOEs $S(\cdot)$, is given by

$$
S\left(\tau_{d}, \tau_{l}, \gamma\right)=\frac{\phi}{1-\phi}\left[1+\frac{R-1}{R} \frac{\gamma}{1-\gamma} \frac{1}{\phi}\left(1-R_{l} b_{f}\right)\right]
$$

where the interest rates $R$ and $R_{l}$ are related to the policy parameters through Eq. (28) and the ratio of capital inflows to output, $b_{f}$, is related to the interest rates and therefore the policy parameters through Eq. (26). Thus, financial repression $(\gamma>0)$ would raise the share of SOE capital to a level above the expenditure share of SOE output, leading to over-investment in the SOE sector.

IV.1. Capital outflow controls and factor allocations. We now examine how changes in the tax rate $\tau_{d}$ on capital outflows could affect the share of capital allocated to the SOE sector measured by $S(\cdot)$.

Using Equations (26), (28), and (30), it is straightforward to show that

$$
\frac{\partial S}{\partial \tau_{d}}=-\frac{R^{*}}{R} \frac{\gamma}{1-\gamma} \frac{1}{1-\phi} \frac{D}{Y}+\frac{R-1}{R} \frac{\gamma}{1-\gamma} \frac{R^{*}}{1-\phi}\left(\frac{1}{1-\gamma} b_{f}+\frac{1}{\Phi_{b}} \frac{1}{R-\gamma}\right)
$$

where $\frac{D}{Y}=\frac{B_{s}+B_{p}-B_{f}}{Y}=\frac{1}{R}\left(1-R_{l} b_{f}\right)$ is the deposit-to-output ratio, which is positive in the interior equilibrium (with a sufficiently small external debt-to-output ratio).

The first term in the expression for $\frac{\partial S}{\partial \tau_{d}}$ is negative, suggesting that a relaxation of capital outflow controls (i.e., a decline in $\tau_{d}$ ) raises the share of capital held by SOEs. The decline in $\tau_{d}$ pushes up domestic interest rates. Since SOEs have access to directed lending, the funding cost for SOEs is less sensitive to changes in market lending rates than that of POEs. The increase in domestic interest rates will thus shift resources towards SOEs. The second term is positive, implying that a reduction in outflow taxes and the resulting increase in domestic lending rates attracts capital inflows, which disproportionately benefits POEs.

The relative strength of the capital-inflow channel (the second term in equation (31)) depends on the level of $\tau_{d}$. Under a lower level of $\tau_{d}$, domestic interest rates and capital inflows $\left(b_{f}\right)$ are higher in the steady state. As a result, the capital-inflow effects 
on resource reallocations would be more likely to dominate, and a reduction in capital outflow taxes would more likely reallocate resources to the POE sector. However, at higher values of $\tau_{d}$, the inflow channel would be more muted. In the extreme, with $\tau_{d}=1-\frac{1}{R^{*}}$, the domestic interest rate is forced down to zero $(R=1)$ and the second term in Equation (31) drops out. Accordingly, in that extreme case, a relaxation of capital outflow controls would unambiguously increase the SOE share.

The following proposition summarizes these results.

Proposition IV.1. For given values of $\tau_{l}<1$ and $\gamma>0$, there exists a threshold value of the capital outflow tax rate $\bar{\tau}_{d} \in\left(-\infty, 1-\frac{1}{R^{*}}\right)$, such that the relative size of the SOE sector measured by $S\left(\tau_{d}, \tau_{l}, \gamma\right)$ increases with $\tau_{d}$ if and only if $\tau_{d} \leq \bar{\tau}_{d}$.

Proof. See Appendix A.

Proposition IV.1 suggests that, holding other policy parameters constant, lowering capital outflow taxes can reduce the size of the SOE sector for sufficiently small values of the initial outflow tax rate.

IV.2. Capital inflow controls and factor allocations. Holding $\tau_{d}$ and $\gamma$ constant, a reduction in capital inflow taxes $\left(\tau_{l}\right)$ unambiguously benefits the POEs more than the SOEs, as it impacts directly on market lending rates, to which POE funding costs are more sensitive. Thus, cutting capital inflow taxes leads to a reallocation of capital and labor from the SOEs to the POEs. This result is formally stated in the proposition below.

Proposition IV.2. For given values of $\tau_{d}<1-\frac{1}{R^{*}}$ and $\gamma>0$, the relative size of the $S O E$ sector $S\left(\tau_{d}, \tau_{l}, \gamma\right)$ increases with $\tau_{l}$.

Proof. Differentiating Eq. (30) with respect to $\tau_{l}$, we obtain

$$
\frac{\partial S}{\partial \tau_{l}}=\frac{R-1}{R} \frac{\gamma}{1-\gamma} \frac{1}{1-\phi} R_{l} \frac{1}{\Phi_{b}} \frac{1}{1-\tau_{l}}>0 .
$$

IV.3. Financial reform and factor allocations. We next examine the effects of changes in financial repression $(\gamma)$ on factor allocations across the two sectors. Eq. (30) implies that

$$
\frac{\partial S}{\partial \gamma}=(R-1) \frac{1}{1-\phi} \frac{1}{(1-\gamma)^{2}} \frac{D}{Y}-\frac{R-1}{R} \frac{\gamma}{1-\gamma} \frac{1}{1-\phi} \frac{R-1}{(1-\gamma)^{2}}\left(b_{f}+\frac{1}{\Phi_{b}}\right) .
$$

Reducing financial repression lowers the market lending rate, lowering POE funding costs and reallocating capital and labor towards POEs. However, the decline in the 
market interest rate discourages foreign capital inflows, hurting POEs more than SOEs. Thus, the net effect of a decline in $\gamma$ on the relative size of the SOE sector $S(\cdot)$ depends on the initial value of $\gamma$. A small value of $\gamma$ weakens the capital inflow effect, implying that $\frac{\partial S}{\partial \gamma}>0$. A large value of $\gamma$ has the opposite impact. The following proposition formalizes this result.

Proposition IV.3. For any given values of $\tau_{l}<1$ and $\tau_{d}<1-\frac{1}{R^{*}}$, there exists a threshold value $\bar{\gamma} \in(0,1)$, such that the relative size of the $S O E$ sector $S\left(\tau_{d}, \tau_{l}, \gamma\right)$ increases with $\gamma$ if and only if $\gamma \leq \bar{\gamma}$.

Proof. See Appendix A.

IV.4. Sectoral allocations and aggregate productivity. Since firms in the SOE sector have lower average productivity than those in the POE sector, an increase in the relative size of the SOE sector $(S(\cdot))$ reduces aggregate productivity. Policy reforms (i.e., changes in $\tau_{d}, \tau_{l}$, and $\gamma$ ) affect aggregate productivity through this reallocation channel.

Define aggregate total factor productivity (TFP) as

$$
\tilde{A}=\frac{Y}{K^{\alpha} H^{1-\alpha}} .
$$

Given that $K=K_{s}+K_{p}$ and $H=H_{s}+H_{p}$ and equation (23), aggregate $\operatorname{TFP}(\tilde{A})$ can be expressed as a function of the relative size of the SOE sector

$$
\tilde{A}=A_{s}^{\phi} A_{p}^{1-\phi} \frac{S^{\phi}}{1+S},
$$

where $A_{s}$ and $A_{p}$ denote the exogenous levels of productivity in the SOE and POE sectors, respectively.

Proposition IV.4. Under any given policy configurations $\left(\tau_{d}, \tau_{l}, \gamma\right)$, aggregate TFP

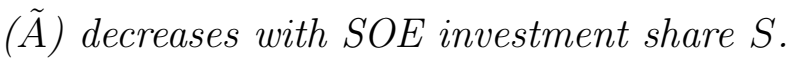

Proof. Differentiating $\tilde{A}$ with respect to $S$ in Eq. (35), we obtain

$$
\begin{aligned}
\frac{\partial \tilde{A}}{\partial S} & =\tilde{A} \frac{1-\phi}{S(1+S)}\left[\frac{\phi}{1-\phi}-S\right] \\
& =-\tilde{A} \frac{1-\phi}{S(1+S)} \frac{\phi}{1-\phi}(R-1) \frac{\gamma}{1-\gamma} \frac{1}{\phi} \frac{D}{Y}<0 .
\end{aligned}
$$

where we have used the expression for $S$ in equation (30) and that the domestic debt-to-output ratio $\frac{D}{Y}>0$. 


\section{Calibration}

We illustrate the tradeoffs of capital account liberalization under financial repression using numerical solutions with the calibrated parameters in Table 1. Where possible, we calibrate to match the observed moments in Chinese data.

We set the subjective discount factor to $\beta=0.665$, which implies an annualized discount factor of 0.96 since we interpret a period in our model as 10 years. We set $\eta=2$, implying a Frisch labor supply elasticity of 0.5 , which lies in the range of empirical studies. We calibrate $\Psi_{h}=38$ such that the steady state value of labor hour is about one-third of total time endowment (which itself is normalized to 1 ). For the parameters in the capital accumulation process, we calibrate $\delta=0.651$, implying an annual depreciation rate of $10 \%$. We set the capital adjustment cost parameter to $\Omega_{k}=5$, which lies in range of the empirical estimates in DSGE models. We set the foreign interest rate to $R^{*}=1.629$, implying an annualized rate of $5 \%$. We calibrate the steady-state value of $\Gamma$, the share of the old-age income bequest to 0.75 , implying an annual household consumption to net worth ratio $\frac{C^{y}+C^{o}}{10\left(D+B_{f}^{d}+q_{k} K\right)}$ of $7 \%$, consistent with the 2011 China Household Finance Survey. We set the elasticity of substitution between SOE output and POE output to $\sigma_{m}=3$, which lies in the range estimated by Chang et al. (2016). ${ }^{21}$

For the parameters related to intermediate goods producers, we calibrate the labor income share to $\alpha=0.5$ based on the empirical evidence documented by Brandt et al. (2008) and Zhu (2012).

We normalize the scale of SOE total factor productivity (TFP) to $A_{s}=1$ and calibrate the scale of POE TFP parameter to $A_{p}=1.42$, consistent with the TFP gap estimated by Hsieh and Klenow (2009). In our transition analysis, we vary the expenditure share of SOE goods $\phi$ to capture structural changes in China. We set $\phi=0.5$ in the initial steady state and consider a lower value of $\phi=0.3$ for the new steady state. These values of $\phi$ are broadly in line with the observed declines in the SOE share in China's industrial output from 2000 to 2010 [e.g. Chen et al. (2017)].

For the baseline policy parameters, we set the share of directed lending to $\gamma=0.5$. According to China's Annual Survey of Industrial Firms, the share of SOE current

\footnotetext{
${ }^{21}$ Chang et al. (2016) estimate that the elasticity of substitution between SOE and POE outputs is about 4.53 if annual output data are used. The estimated elasticity is about 1.92 if monthly sales are used to measure output. Our results are robust to alternative values of $\sigma_{m}$ within a reasonable range, as we show in the online appendix at https://www.frbsf.org/economic-research/ files/wp2018-10_appendix.pdf.
} 
liabilities in all industrial firms was about $60 \%$ in 2000 . At that time, most SOE bank loans constituted directed lending, so a value of $\gamma=0.5$ seems plausible. We set the baseline capital outflow tax rate to $\tau_{d}=15.84 \%$, which implies that $\frac{B_{f t}^{d}}{Y_{t}}=0.06$ in the initial steady state, consistent with the average ratio of domestic private holdings of foreign assets to aggregate output in the Chinese data from 2004 to 2017. We set the baseline capital inflow tax rate to $\tau_{l}=6.47 \%$, so that the steady-state ratio of foreign debt to aggregate output is $\frac{B_{f t}^{l}}{Y_{t}}=0.04$, consistent with the Chinese data. In particular, according to the 2016 Annual Report of SAFE, the ratio of China's foreign liabilities to its annual GDP stayed roughly constant, and averaged about $40 \%$ from 2006 to $2016 .{ }^{22}$ We set the targeted steady-state foreign debt-to-output ratio to $\kappa_{f}=0.04$, such that the risk premium on external debt is zero in the initial steady state under the baseline policy. When the economy deviates from the initial steady state, however, the value of $\kappa_{f}$ stays constant whereas the foreign debt-tooutput ratio varies endogenously. We set the risk premium parameter on foreign debt to $\Phi_{b}=3$, which is consistent with the elasticity of emerging market sovereign bond spread to external debt-to-GDP ratio estimated by Bellas et al. (2010).

\section{Capital account liberalization: Comparative statics}

We now use the calibrated model to examine the implications of alternative liberalization policies for equilibrium allocations and welfare. Through this analysis, we highlight the tradeoff between aggregate productivity and intertemporal allocative efficiency that arises when the capital account is liberalized under financial repression.

We take financial repression as given, and consider three alternative capital account liberalization policies: (i) a one-way liberalization of capital outflows, (ii) a one-way liberalization of capital inflows, and (iii) liberalizing controls over both capital outflows and inflows.

VI.1. Liberalizing capital outflow controls. We begin by examining the steadystate implications of a one-way liberalization of controls on capital outflows by reducing the capital outflow tax rate $\tau_{d}$, while holding the inflow tax rate $\tau_{l}$ and the financial repression parameter $\gamma$ constant.

Figure 3 shows the relation between several key variables in the steady-state equilibrium (the vertical axis in each panel) and the capital outflow tax rate $\tau_{d}$ (the horizontal axis). If $\tau_{d}$ is sufficiently high, households will not invest abroad. When $\tau_{d}$ declines sufficiently, however, households begin to invest a fraction of their savings

\footnotetext{
${ }^{22}$ See Table S3, "China's International Investment Position, 2004-2016" in the SAFE report.
} 
abroad, raising foreign asset holdings while reducing domestic bank deposits. No arbitrage implies that the domestic deposit interest rate rises to the level of the after-tax returns on foreign assets. The increased asset returns alleviate the distortion on the households' consumption-savings decisions.

Under financial repression, the bank passes through increases in the deposit rate to the domestic loan rate. This impacts more on the POE firms, as a portion of SOE borrowing takes place at unaffected directed lending rates. Liberalizing capital outflow controls therefore reallocates resources from to the SOEs, reducing aggregate TFP. At the same time, the increases in the market loan rate attracts foreign capital inflows, alleviating the increases in POEs' funding costs. At very low capital outflow tax rates, further liberalization reverses the TFP decline. Overall, the tradeoff between aggregate productivity and intertemporal efficiency results in an interior optimum.

VI.2. Liberalizing capital inflow controls. Figure 4 displays the steady-state relationship between the capital inflow tax rate $\left(\tau_{l}\right)$ and several macroeconomic variables. Given a sufficiently high inflow tax rate, the country is in financial autarky. However, liberalizing inflow controls raises foreign investors' after-tax returns and eventually induces foreign inflows, reducing the domestic market lending rate. This disproportionately benefits POEs, as SOE directed lending rates are unchanged. As a result, relative POE activity expands, improving aggregate productivity. This positive reallocation effect, however, is partly offset by the over-borrowing externality, because the risk premium on foreign debt increases.

Given directed lending, banks must reduce deposit interest rates to remain solvent, exacerbating the distortion on the households' intertemporal consumption-savings decision. When the domestic deposit rate falls sufficiently, however, households begin to acquire foreign assets, leading to capital outflows.

Overall, liberalizing capital inflow controls improves aggregate productivity, but it exacerbates intertemporal misallocation and the over-borrowing externality. The net effect on welfare is thus ambiguous. As shown in Figure 4, there is an interior optimum that maximizes the representative household's welfare. Moreover, under optimal steady-state capital controls, there is a negative relation between obtainable welfare and the intensity of financial repression $(\gamma)$. Lowering the share of directed lending increases aggregate TFP through sectoral reallocation and also benefits households by increasing returns on savings, raising welfare. 
VI.3. Two-way capital account liberalization. We next examine the steady-state implications of liberalizing capital controls for both inflows and outflows (parameterized by $\tau_{l}$ and $\tau_{d}$ ), taking different values of financial repression $(\gamma)$ as given.

Figure 5 shows that more severe financial repression raises optimal restrictions on both capital inflows and outflows. An increase in $\gamma$ requires an increase in the market lending rate to keep banks solvent. The increased market lending rates reallocate activity towards the less productive SOE sector, lowering TFP. To alleviate this misallocation effect, the planner raises the capital outflow tax $\left(\tau_{d}\right)$, because tighter outflow controls help retain household deposits in domestic banks and therefore dampen the increase in domestic lending rates. However, the increase in the market interest rate also induces increased capital inflows, raising the risk premium and the over-borrowing externality. The planner partly addresses this source of inefficiency by raising the capital inflow tax rate $\tau_{l}$, as shown in Figure 5.

\section{Capital account liberalization: Transition Dynamics}

The Chinese economy has gone through large structural changes over the past few decades. One remarkable structural change is the steady decline in the share of SOE output in total industrial revenue, which declined from about 50\% in 2000 to about $30 \%$ in 2010, and further to about $20 \%$ by 2016 (Chang et al., 2016). In this section, we investigate the optimal path for transition under these structural changes by considering a counterfactual experiment in which the share of SOE input $\phi$ falls from $\phi_{0}=0.5$ in period zero (the initial steady-state value) to $\phi_{1}=0.3$ in period $t=1$ and stays at that level thereafter (the new steady-state value). In particular, we examine the optimal magnitude and speed of capital account liberalization that maximizes social welfare along the transition paths between these two steady states.

To illustrate the counterfactual policy experiments, consider first the case with capital outflow liberalization. Denote by $\tau_{d 0}$ the pre-liberalization tax rate on capital outflows; that is, the tax rate in the initial steady state with the high level of the SOE expenditure share. Denote by $\tau_{d 1}$ the post-liberalization tax rate on capital outflows. We assume that the government pursues its liberalization policy at a pace measured by $\alpha_{d} \in[0,1]$. The transition path of the capital outflow tax rate is then given by

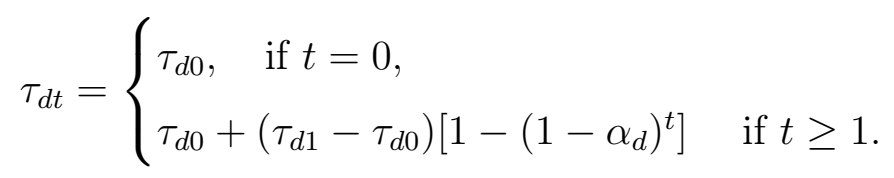


If $\alpha_{d}$ is zero, then $\tau_{d t}$ would stay at the initial value of $\tau_{d 0}$ permanently. If $\alpha_{d}$ is one, then $\tau_{d t}$ would jump to the new steady state value of $\tau_{d 1}$ immediately after the initial period. If $\alpha_{d} \in(0,1)$, then the change in $\tau_{d t}$ would be gradual.

Similarly, denote the pre- and post-liberalization capital inflow tax rates by $\tau_{l 0}$ and $\tau_{l 1}$, respectively, and the pace of capital inflow liberalization by $\alpha_{l}$. We also denote the pre- and post-liberalization financial repression by $\gamma_{0}$ and $\gamma_{1}$ respectively, and the pace of financial liberalization by $\alpha_{\gamma}$.

Given these notations, we define the transition welfare as

$$
V_{1}\left(\tau_{d 1}, \tau_{l 1}, \gamma_{1} ; \alpha_{d}, \alpha_{l}, \alpha_{\gamma}\right)=\sum_{t=1}^{\infty} \beta^{t}\left(\ln \left(C_{t}^{y}\right)-\Psi_{h} \frac{H_{t}^{1+\eta}}{1+\eta}+\ln \left(C_{t}^{o}\right)\right)
$$

where $C_{t}^{y}$ and $C_{t}^{o}$ denote the consumption of the young and the old, and $H_{t}$ denotes the labor supply of the young generation, along the transition path. The transition welfare $V_{1}$ depends on both the magnitudes of the new policy parameters $\left(\tau_{d 1}, \tau_{l 1}, \gamma_{1}\right)$ and the paces of liberalization $\left(\alpha_{d}, \alpha_{l}, \alpha_{\gamma}\right)$.

Table 2 (Panel A) shows the policy parameters and the welfare gains under several alternative policy liberalization scenarios relative to the baseline policy regime (Case $0)$ in the benchmark model.

The first liberalization scenario (Case 1) focuses on liberalizing capital inflow controls and financial repression, while keeping the capital outflow tax rate at its initial steady-state level. The planner chooses both the magnitude and the pace of inflow liberalization $\left(\tau_{l 1}\right.$ and $\left.\alpha_{l}\right)$ and domestic financial reforms $\left(\gamma_{1}\right.$ and $\left.\alpha_{\gamma}\right)$ to maximize the transition welfare defined in (38). Under this policy, the share of directed lending to SOEs falls sharply from $\gamma_{0}=50 \%$ to $\gamma_{1}=0.00 \%$ in the new steady state and the financial reform is implemented immediately $\left(\alpha_{\gamma}=100 \%\right)$. The planner also chooses to subsidize capital inflows $\left(\tau_{l 1}=-4.55 \%\right)$ in the new steady state, and to implement the liberalization of capital inflows at a gradual pace $\left(\alpha_{l}=29.21 \%\right)$.

By removing directed lending immediately, the financial reform reduces the wedge between domestic market lending rate and the deposit rate and thus lowers POE funding costs. This improves capital allocations, raises aggregate TFP, and accelerates the transition. However, the decline in the domestic lending rate also discourages foreign capital inflows. The planner provides a modest subsidy to capital inflows to mitigate their declines following the financial liberalization. Relative to the baseline regime, this set of policy reforms leads to a welfare gain of about $5.21 \%$ in consumption equivalent units along the transition paths. 
The second liberalization scenario (Case 2) focuses on liberalizing capital outflow controls and financial repression, holding the capital inflow tax rate at its initial steady-state level. The planner chooses the magnitude and the pace of capital outflow liberalization $\left(\tau_{l 1}\right.$ and $\left.\alpha_{l}\right)$ and financial reforms $\left(\gamma_{1}\right.$ and $\left.\alpha_{\gamma}\right)$ to maximize the transition welfare, taking inflow taxes as given. The planner again chooses to eliminate financial repression at a fast pace $\left(\alpha_{\gamma}=99.99 \%\right),{ }^{23}$ and to implement a small subsidy for capital outflows $\left(\tau_{d 1}=-1.48 \%\right)$ at a gradual pace $\left(\alpha_{d}=45.95 \%\right)$. The financial reform helps reduce $\mathrm{POE}$ funding costs, and thus improves aggregate productivity and accelerates the transition. The capital outflow subsidy raises the returns on household savings, alleviating intertemporal distortions. This raises welfare relative to the baseline policy regime, with a transition welfare gain of about $7.44 \%$ in consumption equivalent units.

The third liberalization scenario (Case 3) features full reforms, with all the policy parameters chosen optimally to maximize the transition welfare. Similar to the two cases with partial reforms, the planner chooses to eliminate directed lending almost instantaneously (by setting $\gamma_{1}=0$ and $\alpha_{\gamma}=99.96 \%$ ). The planner also chooses to relax capital controls by reducing the inflow tax rate (from $\tau_{l 0}=6.47 \%$ to $\tau_{l 1}=$ $3.09 \%$ ) and replacing outflow taxes by a small subsidy (changing from $\tau_{d 0}=15.84 \%$ to $\left.\tau_{d 1}=-0.99 \%\right)$. While capital inflow liberalization is implemented immediately $\left(\alpha_{l}=\right.$ $100 \%)$, outflow liberalization is pursued at a much more gradual pace $\left(\alpha_{d}=41.83 \%\right)$. As in the cases with partial reforms (Cases 1 and 2), the financial reform and capital inflow liberalization both help reduce POE's funding costs and thus improve capital allocations and aggregate TFP, while subsidizing capital outflows raises the returns on household savings and alleviates intertemporal distortions. The relatively slow pace of capital outflow liberalization reflects the planner's desire to accelerate the transition to a smaller SOE sector, while mitigating the costs of investment adjustment. The full reforms lead to a welfare gain of about $7.51 \%$ in consumption equivalent units.

The magnitude of welfare gains in each of the liberalization scenarios is sizable. However, the welfare gains under the full reforms (Case 3) are not much larger than those under partial reforms (Cases 1 and 2), suggesting that the bulk of the welfare gains stem from removing financial repression.

Although the relative ordering of liberalizing capital inflows and outflows may depend on the model parameters, a robust finding from our analysis is that optimal

\footnotetext{
${ }^{23}$ The share of directed lending under the liberalization policy is slightly positive (at $0.08 \%$ ) to mitigate the distortion on inflows associated with inflow taxes.
} 
policy along the transition path calls for domestic financial reforms to be implemented at a relatively faster pace than capital account liberalization.

\section{FinANCIAL REPRESSiOn With SOE BAILOUT GUARANTEES}

In the benchmark model, we assume that SOEs have access to directed lending at a zero interest rate. Thus, the funding costs for SOEs respond to market interest rates only to the extent that SOEs choose to borrow in excess of the level of directed lending. Increases in the market loan interest rate creates a wedge relative to the deposit rate-a form of financial repression-that plays a key role in generating the tradeoffs for capital account liberalization policies observed above. Our simple benchmark model allows for analytic results that illustrate the reallocation mechanism under liberalization policies. We now examine the robustness of this mechanism by studying an alternative form of financial repression that better captures the actual lending policy favoring SOEs in China.

As in the benchmark model, we consider an environment in which the government requires the bank to offer a constant fraction of their domestic loans to SOEs in the form of directed lending, but now we assume that these directed loans are guaranteed in the sense that the government would make up the losses to the bank in the event of defaults on these loans. No such guarantees are offered for market loans. For simplicity, we assume that there is no explicit output losses from defaults (i.e., no monitoring cost). The government finances its SOE bailout costs through lump-sum taxes on the banking sector. The bank therefore charges a spread between the lending interest rate and the deposit rate to cover its share of the SOE bailout costs, leading to a form of financial repression. The guarantees on directed lending therefore reduce the funding costs for SOEs relative to those for POEs, generating misallocations. ${ }^{24}$

VIII.1. The model elements. The model builds on the Bernanke et al. (1999) (BGG) framework with equilibrium defaults and credit spreads. We follow Chang et al. (2019) and extend the BGG framework to a two-sector environment. The model differs from our benchmark model only in the specifications of intermediate

\footnotetext{
${ }^{24}$ Liu et al. (2020) study the implications of liberalizing China's interest-rate controls for misallocations. In their model, interest-rate controls take the form of an exogenous wedge between the loan interest rate and the deposit rate, which is a form of financial repression. SOEs have better access to bank credit than POEs because SOEs face a higher loan-to-value ratio. Unlike our bailout specification, firms do not default in their model, and they focus on a closed-economy environment for studying interest rate liberalization.
} 
goods production and financial frictions. We highlight the main model elements here and provide details in the online Appendix. ${ }^{25}$

There is a continuum of intermediate goods producers in each of the two sectors (SOEs and POEs). Each firm operates a Cobb-Douglas technology that transforms capital and labor inputs ( $K_{j t}$ and $L_{j t}$, respectively) into intermediate goods output $Y_{j t}$, with a sector-specific productivity $A_{j}$. Firms in each sector also face an idiosyncratic productivity $\omega_{j t}$, which is drawn from the i.i.d. distribution $F(\cdot)$ with a non-negative support. The production function is given by

$$
Y_{j t}=A_{j} \omega_{j t}\left(K_{j t}\right)^{1-\alpha}\left(H_{j t}\right)^{\alpha}
$$

As in the benchmark model, firms face working capital constraints. Before production takes place, a firm needs to pay wages and capital rents with working capital loans $B_{j t}$ obtained from banks. The firm repays the loans at the end of the period when production is completed. The working capital constraint for a firm in sector $j \in\{s, p\}$ takes the same form specified in Eq. (11).

There is a continuum of competitive banks. The representative bank takes deposits from households and lends to SOE and POE firms, subject to the flow-of-funds constraint (14). To capture financial repression in China, we assume that the government guarantees a fraction $\gamma$ of total bank loans, which are directed and must be lent to the SOEs. As in the benchmark model, we assume that the amount of directed lending $\left(B_{g t}\right)$ does not exceed the amount of actual SOE loans, as specified in Eq. 15.

As in Bernanke et al. (1999), firms in each sector are ex ante identical, so that the bank charges a gross loan interest rate of $Z_{j t}(j=s, p)$ to all firms in sector $j$, regardless of their idiosyncratic productivity $\omega_{j t}$. Ex post, firms with sufficiently low levels of productivity cannot repay the loans. Thus, there exists a cut-off level of productivity $\bar{\omega}_{j t}$ such that firms with $\omega_{j t}<\bar{\omega}_{j t}$ choose to default. The cutoff point $\bar{\omega}_{j t}$ satisfies

$$
\bar{\omega}_{j t} \equiv \frac{Z_{j t}}{\tilde{A}_{j t}},
$$

where the term $\tilde{A}_{j t} \equiv \frac{p_{j t} Y_{j t}}{B_{j t}}$ denotes the rate of return on the firm's investment financed by bank loans.

For POE lending, the bank obtains repayments from all non-defaulting firms, with the probability $1-F\left(\bar{\omega}_{p t}\right)$. Firms with low productivity $\left(\omega<\bar{\omega}_{p t}\right)$ choose to default, in which case the bank seizes the project and obtains the realized revenue. Denote

\footnotetext{
${ }^{25}$ The appendix is available at https://www.frbsf.org/economic-research/files/ wp2018-10_appendix.pdf
} 
by $g_{p}\left(\bar{\omega}_{p t}\right)$ the share of income going to the bank on POE loans. The bank's expected income from $\mathrm{POE}$ lending is given by

$$
g_{p t}\left(\bar{\omega}_{p t}\right) \tilde{A}_{p t} B_{p t}^{d}=\left[1-F\left(\bar{\omega}_{p t}\right)\right] Z_{p t} B_{p t}^{d}+\int_{0}^{\bar{\omega}_{p t}} \omega \tilde{A}_{p t} B_{p t}^{d} d F(\omega)
$$

For SOE lending, the bank obtains repayments with the probability $1-F\left(\bar{\omega}_{s t}\right)$. In the event of an SOE default, the bank also takes over the project and obtains the realized revenue. In addition, under the bailout guarantees, the government makes up the losses on a fraction $\frac{B_{g t}}{B_{s t}^{d}} \leq 1$ of the defaulted SOE loans. Denote by $g_{s}\left(\bar{\omega}_{s t}\right)$ the share of income going to the bank on SOE loans. The expected income for the bank on SOE loans is given by

$g_{s t}\left(\bar{\omega}_{s t}\right) \tilde{A}_{s t} B_{s t}^{d}=\left[1-F\left(\bar{\omega}_{s t}\right)\right] Z_{s t} B_{s t}^{d}+\int_{0}^{\bar{\omega}_{s t}}\left\{\omega \tilde{A}_{s t} B_{s t}^{d}+\frac{B_{g t}}{B_{s t}^{d}}\left(Z_{s t} B_{s t}^{d}-\tilde{A}_{s t} \omega B_{s t}^{d}\right)\right\} d F(\omega)$.

Denote by $R_{l t}$ the risk-adjusted rate of return that the bank requires on its loans. The bank's participation constraint is given by,

$$
g_{j}\left(\bar{\omega}_{j t}\right) \tilde{A}_{j t} B_{j t}^{d} \geq R_{l t} B_{j t}^{d}
$$

The government finances its spending on SOE bailout costs by taxing domestic banking activities. Since banks are risk neutral and there is free entry, the representative bank earns zero profits in equilibrium, implying that

$$
\left(R_{l t}-R_{t}\right) D_{t}=B_{g t} \tilde{A}_{s t} \int_{0}^{\bar{\omega}_{s t}}\left(\bar{\omega}_{s t}-\omega\right) d F(\omega) .
$$

This zero-profit condition suggests that the interest rate $R_{l t}$ on market loans that the bank charges needs to exceed the deposit interest rate $R_{t}$ to cover the costs of SOE bailouts. As a result, financial repression drives a wedge between the loan rate and the deposit rate (i.e., a credit spread).

Denote by $f\left(\bar{\omega}_{j t}\right)$ the share of income going to firms in section $j \in\{s, p\}$. Under the loan contracts, the expected income for a firm in sector $j$ is given by

$$
f\left(\bar{\omega}_{j t}\right) \tilde{A}_{j t} B_{j t}^{d}=\int_{\bar{\omega}_{j t}}^{\infty} \tilde{A}_{j t} \omega_{j t} B_{j t}^{d} d F(\omega)-\left(1-F\left(\bar{\omega}_{j t}\right)\right) Z_{j t} B_{j t}^{d} .
$$

VIII.2. Model implications. The SOE bailout model is too complex to solve analytically, so we rely on numerical solutions based on calibrated parameters. We describe the model details and parameter calibration in the online Appendix. We solve the model's steady state equilibrium under these parameters and study the transition dynamics and policy reforms in the case with a decline in the SOE share $\phi$. 
The steady-state implications of liberalization are qualitatively similar to those in our benchmark model, as we discuss in the online Appendix. Government guarantees on directed loans reduce the funding costs and credit spreads for SOEs. The bailout guarantees also reduce the sensitivity of SOE funding costs to changes in the domestic deposit rate following liberalization reforms. These distortions lead to over-investment by inefficient SOEs, reducing aggregate productivity. Under this form of financial repression, liberalizing the capital account incurs the same tradeoff between productive efficiency and intertemporal allocative efficiency highlighted in our benchmark model.

Optimal policy and transition welfare following a permanent decline in the SOE share (i.e., $\phi$ drops from 0.5 to 0.3 ) in this model are also similar to those obtained in our benchmark model, as shown in Table 2 (Panel B). In the case in which the planner pursues one-way capital inflow liberalization along with domestic financial reforms (Case 1), optimal policy features an immediate elimination of financial repression $\left(\gamma_{1}=0\right.$ and $\left.\alpha_{\gamma}=100 \%\right)$, combined with a modest subsidy for capital inflows implemented at a gradual pace $\left(\tau_{l 1}=-5.05 \%\right.$ and $\left.\alpha_{l}=24.76 \%\right)$. In the case with oneway capital outflow liberalization and financial reforms (Case 2), optimal policy again features an immediate removal of financial repression and a gradual implementation of a modest outflow subsidy. In the case with full reforms (Case 3), the optimal policy combination features an immediate removal of financial repression and an immediate liberalization of capital inflows, but a gradual liberalization of capital outflows. These liberalization reforms also lead to modest welfare gains along the transition path. Similar to the benchmark model, most welfare gains stem from liberalizing financial repression. Overall, our results are very similar to our benchmark model, demonstrating robustness of our main results to this alternative approach to modeling financial repression.

\section{CONCLUSiON}

We have studied the implications of capital account liberalization in China under financial repression in a small open economy model with overlapping generations. We show that, unless financial repression is lifted, easing capital controls raises a tradeoff between aggregate production efficiency and intertemporal allocative efficiency.

Under financial repression, banks are required to make directed lending to lowproductivity SOEs at below-market interest rates. This generates a wedge between market lending and deposit rates. Since productive private firms can borrow only at 
market interest rates, financial repression leads to a misallocation of resources in favor of excessive SOE production.

Easing capital inflow controls attracts additional foreign funds, reducing private firms' funding costs and enhancing aggregate TFP. However, banks respond to inflowinduced declines in market lending rates by lowering deposit rates, further distorting household consumption-savings decisions. Similarly, easing capital outflow controls improves the returns on household savings, but it pushes up domestic market lending rates, raising funding costs for private firms and reducing TFP.

Our findings provide a second-best argument for moderation in both the pace and the degree of capital account liberalization under financial repression. However, we also find that liberalizing domestic financial markets prior to opening the capital account mitigates the transition costs encountered during the capital account liberalization process. Thus, our analysis suggests that domestic financial reforms and capital account liberalization are complementary and should be pursued jointly.

\section{REFERENCES}

Agarwal, I., G. W. Gu, and E. S. Prasad (2019, September). China's impact on global financial markets. NBER Working Paper No. 26311.

Aoki, K., G. Benigno, and N. Kiyotaki (2009, June). Adjusting to capital account liberalization. Mimeo, London School of Economics and Princeton University.

Bellas, D., M. G. Papaioannou, and I. Petrova (2010, December). Determinants of Emerging Market Sovereign Bond Spreads; Fundamentals vs Financial Stress. IMF Working Papers 10/281, International Monetary Fund.

Bernanke, B., M. Gertler, and S. Gilchrist (1999). The financial accelerator in a quantitative business cycle framework. In J. B. Taylor and M. Woodford (Eds.), Handbook of Macroeconomics, pp. 1341-1393. Amsterdam, New York, and Oxford: Elsevier Science.

Bianchi, J. (2011). Overborrowing and systemic externalities in the business cycle. American Economic Review 101 (7), 3400-3426.

Brandt, L., C.-T. Hsieh, and X. Zhu (2008). Growth and structural transformation in china. In L. Brandt and T. G. Rawski (Eds.), China's Great Economic Transformation, pp. 683-728. Cambridge University Press.

Brandt, L. and X. Zhu (2000). Redistribution in a decentralized economy. Journal of Political Economy 108(2), 422-439. 
Chang, C., K. Chen, D. F. Waggoner, and T. Zha (2016). Trends and cycles in china's macroeconomy. In M. Eichenbaum and J. Parker (Eds.), NBER Macroeconomics Annual 2015, Volume 30, pp. 1-84. University of Chicago Press.

Chang, C., Z. Liu, and M. M. Spiegel (2015). Capital controls and optimal chinese monetary policy. Journal of Monetary Economics 74, 1-15.

Chang, C., Z. Liu, M. M. Spiegel, and J. Zhang (2019). Reserve requirements and optimal chinese stabilization policy. Journal of Monetary Economics 103, 33-51.

Chen, K., P. Higgins, D. F. Waggoner, and T. Zha (2017, September). Impacts of monetary stimulus on credit allocation and macroeconomy: Evidence from china. NBER Working Paper No. 22650.

Chinn, M. and H. Ito (2006). What matters for financial development? Journal of Development Economics 81, 163-192.

Costinot, A., G. Lorenzoni, and I. Werning (2014). A theory of capital controls as dynamic terms of trade manipulation. Journal of Political Economy 122, 77-128.

Davis, J. S. and I. Presno (2017). Capital controls and monetary policy autonomy in a small open economy. Journal of Monetary Economics 85(C), 114-130.

Devereux, M. B., E. R. Young, and C. Yu (2019). Capital controls and monetary policy in sudden-stop economies. Journal of Monetary Economics 103, 52-74.

Edwards, S. (1984). The Order of Liberalization of the External Sector in Developing Countries, Volume 156 of Essays in International Finance. Princeton, New Jersey: Princeton University Press.

Edwards, S. (1999). How effective are capital controls? Journal of Economic Perspectives 13(4), 65-84.

Eichengreen, B., R. Gullapalli, and U. Panizza (2011). Capital account liberalization, financial development and industry growth: A synthetic view. Journal of International Money and Finance 30, 1090-1106.

Eichengreen, B. and D. Leblang (2003). Capital account liberalization and growth: Was mr. mahathir right? The International Journal of Finance and Economics 8(3), 205-224.

Farhi, E. and I. Werning (2012, June). Dealing with the trilemma: Optimal capital controls with fixed exchange rates. NBER Working Paper No. 18199.

Hsieh, C.-T. and P. J. Klenow (2009, November). Misallocation and manufacturing tfp in china and india. The Quarterly Journal of Economics 124(4), 1403-1448.

Hsu, S. (2016). China's banking sector as the foundation of financial reform. Asia and the Pacific Policy Studies 3(2), 244-248. 
Jeanne, O. (2013). Capital account policies and the real exchange rate. In F. Giavazzi and K. D. West (Eds.), NBER International Seminar on Macroeconomics 2012, Volume 9, pp. 7-42. Chicago, IL: University of Chicago Press.

Jeanne, O., A. Subramanian, and J. Williamson (2012). Who needs to open the capital account? Washington, D.C.: Peterson Institute for International Economics.

Ju, J. and S.-J. Wei (2010). Domestic institutions and the bypass effect of financial globalization. American Economic Journal: Policy 2(4), 173-204.

Kose, A., E. Prasad, K. Rogoff, and S.-J. Wei (2009). Financial globalization: A reappraisal. International Monetary Fund Economic Review 56(1), 8-62.

Lardy, N. and P. Douglass (2011, February). Capital account liberalization and the role of the renminbi. Peterson Institute for International Economics Working Paper $11-6$.

Liu, Z. and M. M. Spiegel (2015). Optimal monetary policy and capital account restrictions in a small open economy. IMF Economic Review 63(2), 298-324.

Liu, Z., P. Wang, and Z. Xu (2020). Interest-rate liberalization and capital misallocations. American Economic Journal: Macroeconomics (forthcoming). Federal Reserve Bank of San Francisco Working Paper 2017-15.

Ostry, J. D., A. R. Ghosh, K. Habermeier, M. Chamon, M. S. Qureshi, and D. B. Reinhart (2010, February). Capital inflows: The role of controls. IMF Staff Position Note No. 10/04.

Song, Z., K. Storesletten, and F. Zilibotti (2011). Growing Like China. American Economic Review 101(1), 196-233.

Song, Z., K. Storesletten, and F. Zilibotti (2014). Growing (with capital controls) like china. IMF Economic Review 122, 327-370.

Unsal, D. F. (2013). Capital Flows and Financial Stability: Monetary Policy and Macroprudential Responses. International Journal of Central Banking 9, 233-285.

Wang, P., Y. Wen, and Z. Xu (2015). Two-way Capital Flows and Global Imbalances. Economic Journal 127, 229-269.

Wei, S.-J. (2018, February). Managing financial globalization: Insights from the recent literature. NBER Working Paper No. 24330.

Wei, S.-J. and I. Tytell (2004, May). Does financial globalization induce better macroeconomic policies? IMF Working Papers 04/84, International Monetary Fund.

Wei, S.-J. and Z. Zhang (2007). Collateral Damage: Capital Controls and International Trade. Journal of International Money and Finance 26(5), 841-863. 
Zhu, X. (2012). Understanding china's growth: Past, present, and future. Journal of Economic Perspectives 26(4), 103-124. 
OPTIMAL CAPITAL ACCOUNT LIBERALIZATION IN CHINA

TABLE 1. Parameter calibration

\begin{tabular}{lcc}
\hline \hline Parameter & Description & Value \\
\hline$\beta$ & Household discount rate & 0.665 \\
$\eta$ & Inverse of labor supply elasticity & 2 \\
$\Psi_{h}$ & Utility weight of labor & 38 \\
$\delta$ & Capital depreciation rate & 0.651 \\
$\Omega_{k}$ & Capital adjustment cost & 5 \\
$r^{*}$ & Foreign interest rate & 1.629 \\
$\tau$ & Transfer from old to young & 0.75 \\
$\alpha$ & Labor income share & 0.5 \\
$A_{s}$ & SOE TFP & 1 \\
$A_{p}$ & POE TFP & 1.42 \\
$\phi$ & Share of SOE output & 0.5 \\
$\sigma_{m}$ & Substitution elasticity between SOE and POE products & 3 \\
$\gamma$ & Share of directed lending & 0.5 \\
$\tau_{d}$ & Tax rate on foreign asset & $15.84 \%$ \\
$\tau_{l}$ & Tax rate on foreign debt & $6.47 \%$ \\
$\Phi_{b}$ & Elasticity of risk premium to foreign debt & 3 \\
$\kappa_{f}$ & Desirable foreign debt-to-output ratio & 0.04 \\
\hline \hline
\end{tabular}


TABLE 2. Optimal liberalization policy following a decline in SOE share

\begin{tabular}{|c|c|c|c|c|}
\hline \multicolumn{5}{|c|}{ A: Benchmark model } \\
\hline & Baseline & Inflow only & Outflow only & Full liberalization \\
\hline Case & 0 & 1 & 2 & 3 \\
\hline$\tau_{d}$ & $15.84 \%$ & $15.84 \%$ & $-1.48 \%$ & $-0.99 \%$ \\
\hline$\alpha_{d}$ & - & - & $45.95 \%$ & $41.83 \%$ \\
\hline$\tau_{l}$ & $6.47 \%$ & $-4.55 \%$ & $6.47 \%$ & $3.09 \%$ \\
\hline$\alpha_{l}$ & - & $29.21 \%$ & - & $100.00 \%$ \\
\hline$\gamma$ & $50.00 \%$ & $0.00 \%$ & $0.08 \%$ & $0.00 \%$ \\
\hline$\alpha_{\gamma}$ & - & $100.00 \%$ & $99.99 \%$ & $99.96 \%$ \\
\hline Welfare gains & $0.00 \%$ & $5.21 \%$ & $7.44 \%$ & $7.51 \%$ \\
\hline \multicolumn{5}{|c|}{ B: Model with SOE bailout guarantees } \\
\hline & Baseline & Inflow only & Outflow only & Full liberalization \\
\hline Case & 0 & 1 & 2 & 3 \\
\hline$\overline{\tau_{d}}$ & $15.82 \%$ & $15.82 \%$ & $-1.44 \%$ & $-1.06 \%$ \\
\hline$\alpha_{d}$ & - & - & $46.55 \%$ & $43.43 \%$ \\
\hline$\tau_{l}$ & $5.87 \%$ & $-5.05 \%$ & $5.87 \%$ & $3.44 \%$ \\
\hline$\alpha_{l}$ & - & $24.76 \%$ & - & $100.00 \%$ \\
\hline$\gamma$ & $50.00 \%$ & $0.00 \%$ & $0.00 \%$ & $0.00 \%$ \\
\hline$\alpha_{\gamma}$ & - & $100.00 \%$ & $99.93 \%$ & $99.98 \%$ \\
\hline Welfare gains & $0.00 \%$ & $3.60 \%$ & $5.90 \%$ & $5.93 \%$ \\
\hline
\end{tabular}

Note: Panel A shows the optimal policy parameters and welfare gains relative to the baseline with no liberalization in the benchmark model. Panel B shows those in the alternative model with the government providing bailout guarantees for directed loans to SOEs. In each model, welfare gains are expressed in terms of consumption equivalent per period. Case 0 is the baseline where all policy parameters are kept constant at its initial steady state level. In Case 1, the planner chooses the capital inflow parameters $\left(\tau_{l 1}\right.$ and $\left.\alpha_{l}\right)$ and the financial repression parameters $\left(\gamma_{1}\right.$ and $\left.\alpha_{\gamma}\right)$ to maximize the transition welfare, holding the capital outflow parameters $\left(\tau_{d 1}\right.$ and $\left.\alpha_{d}\right)$ constant. In Case 2 , the planner keeps the inflow control parameters at their initial steady state levels and chooses the outflow control parameters and the financial repression parameters to maximize the transition welfare. In Case 3, the planner implements a full reform by choosing all policy parameters to maximize the transition welfare. 

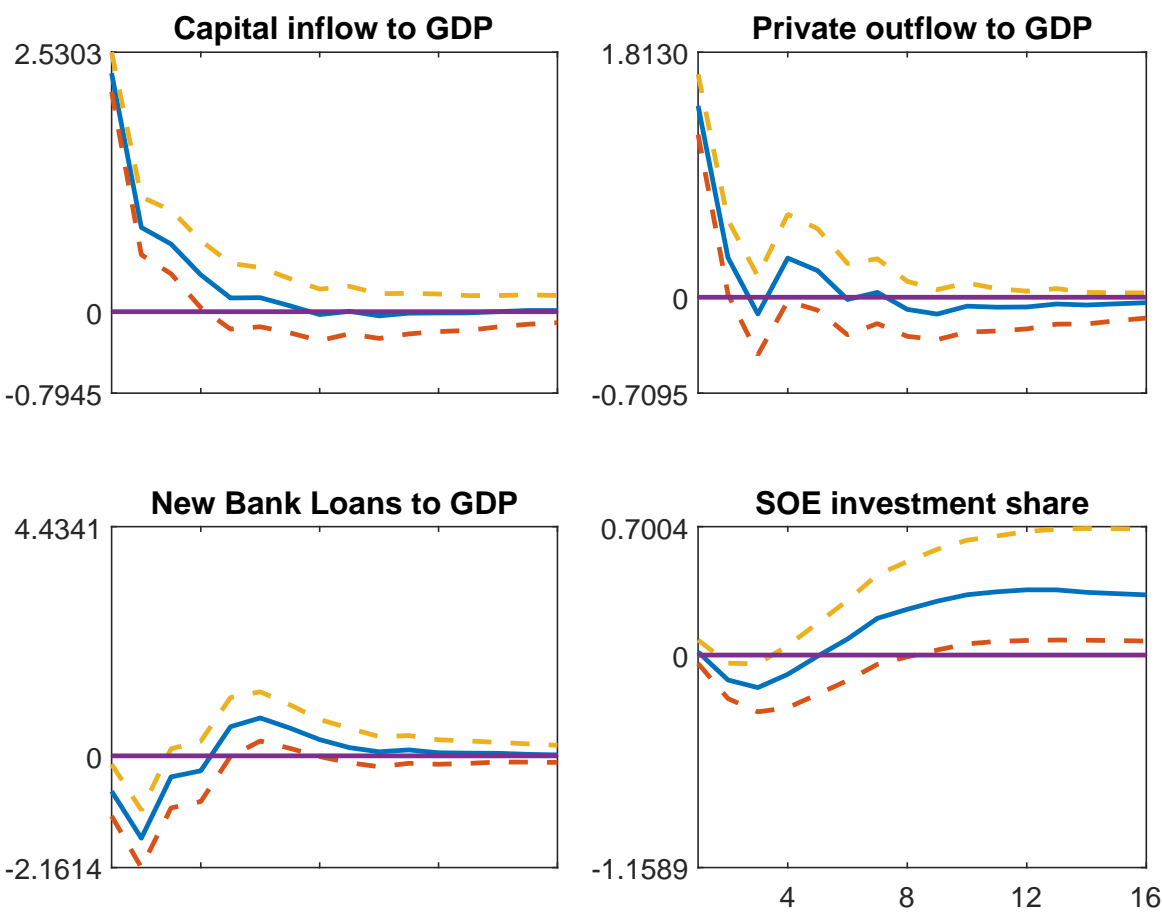

FiguRE 1. Impulse responses to a positive shock to capital inflows in an estimated BVAR model. The model includes the ratio of capital inflows to GDP, the ratio of private capital outflows to GDP, and the SOE investment share, in that order. The solid lines indicate the median impulse responses, and the dashed lines indicate the $68 \%$ probability intervals. 

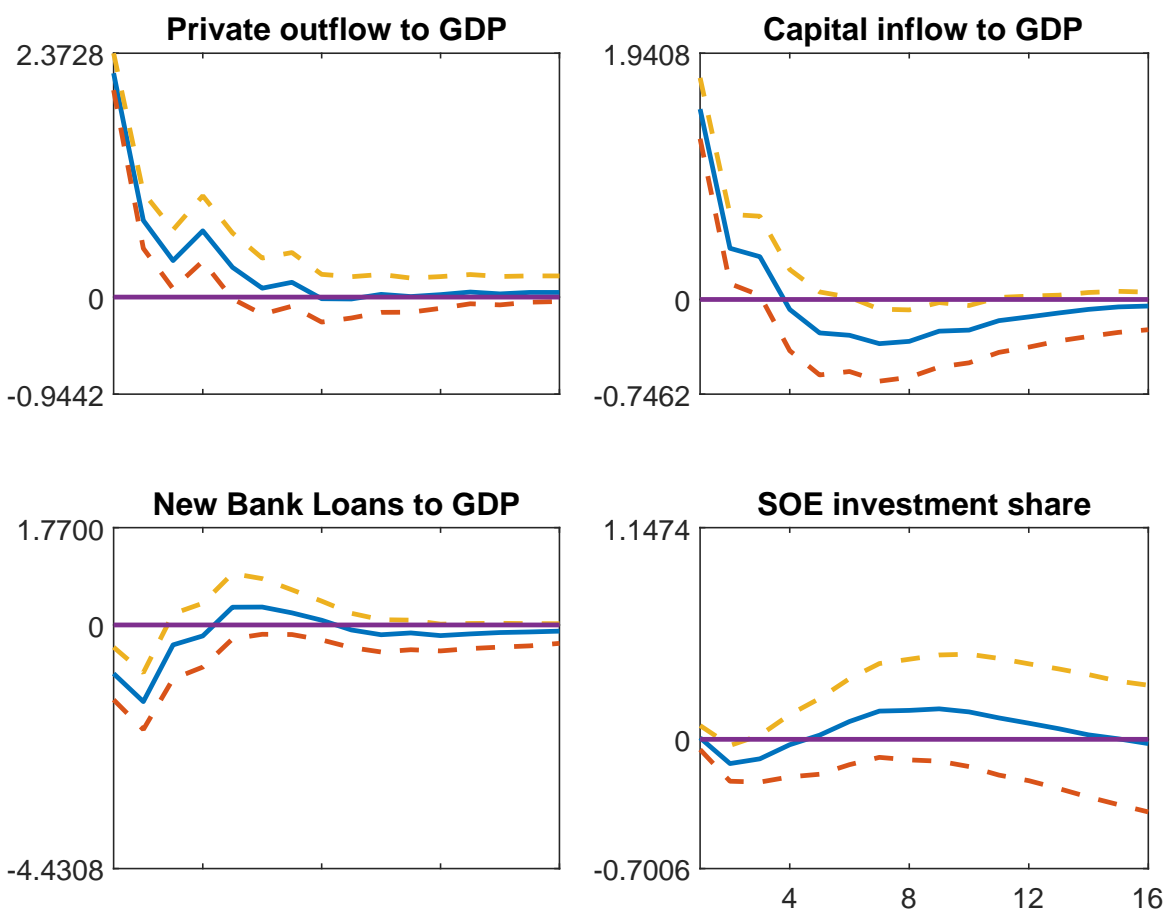

Figure 2. Impulse responses to a positive shock to capital outflows in an estimated BVAR model. The model includes the ratio of private capital outflows to GDP, the ratio of capital inflows to GDP, and the SOE investment share, in that order. The solid lines indicate the median impulse responses, and the dashed lines indicate the $68 \%$ probability intervals. 
OPTIMAL CAPITAL ACCOUNT LIBERALIZATION IN CHINA
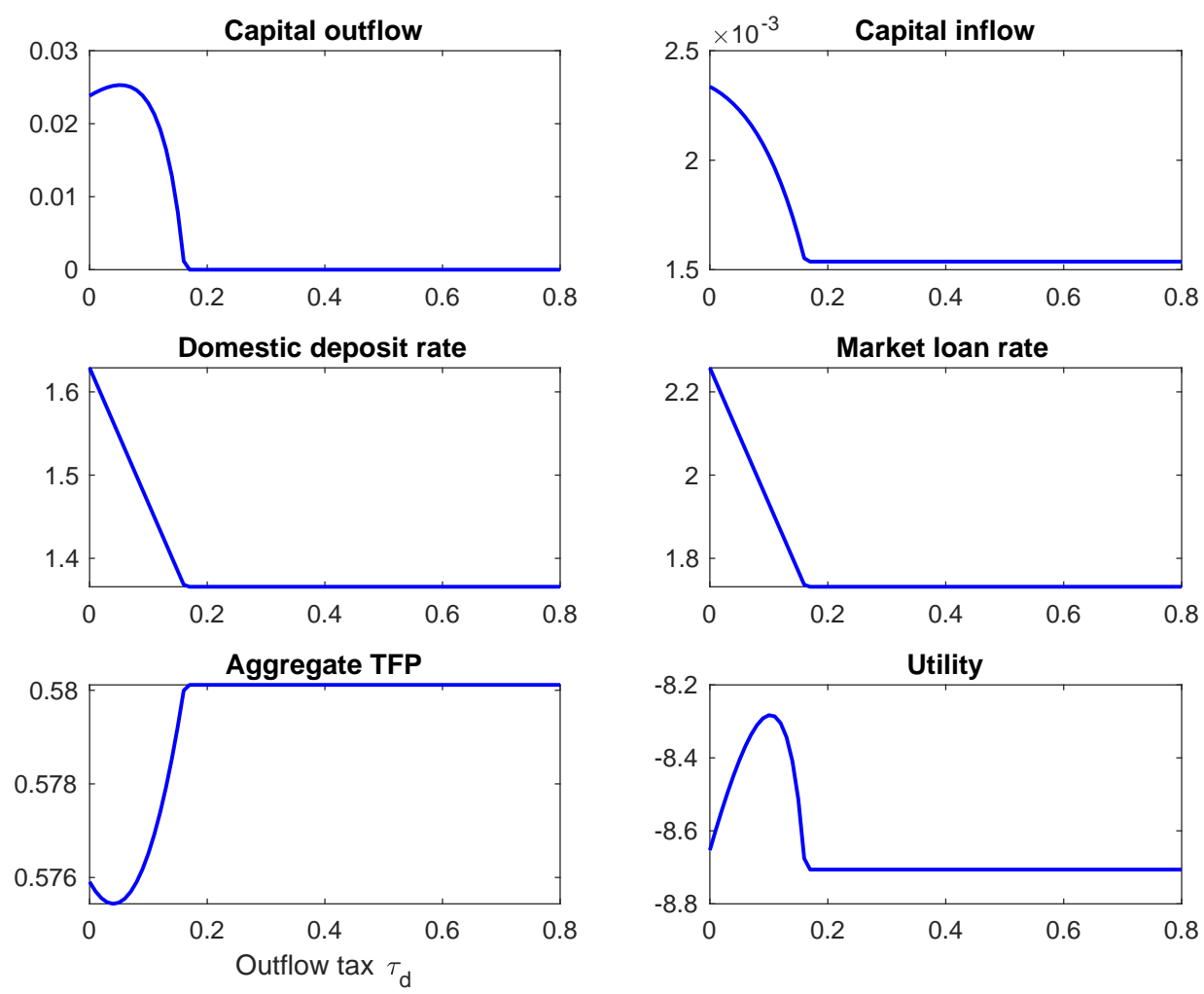

FigURE 3. Steady-state implications of a one-way liberalization of capital outflow controls in the benchmark model. 
OPTIMAL CAPITAL ACCOUNT LIBERALIZATION IN CHINA
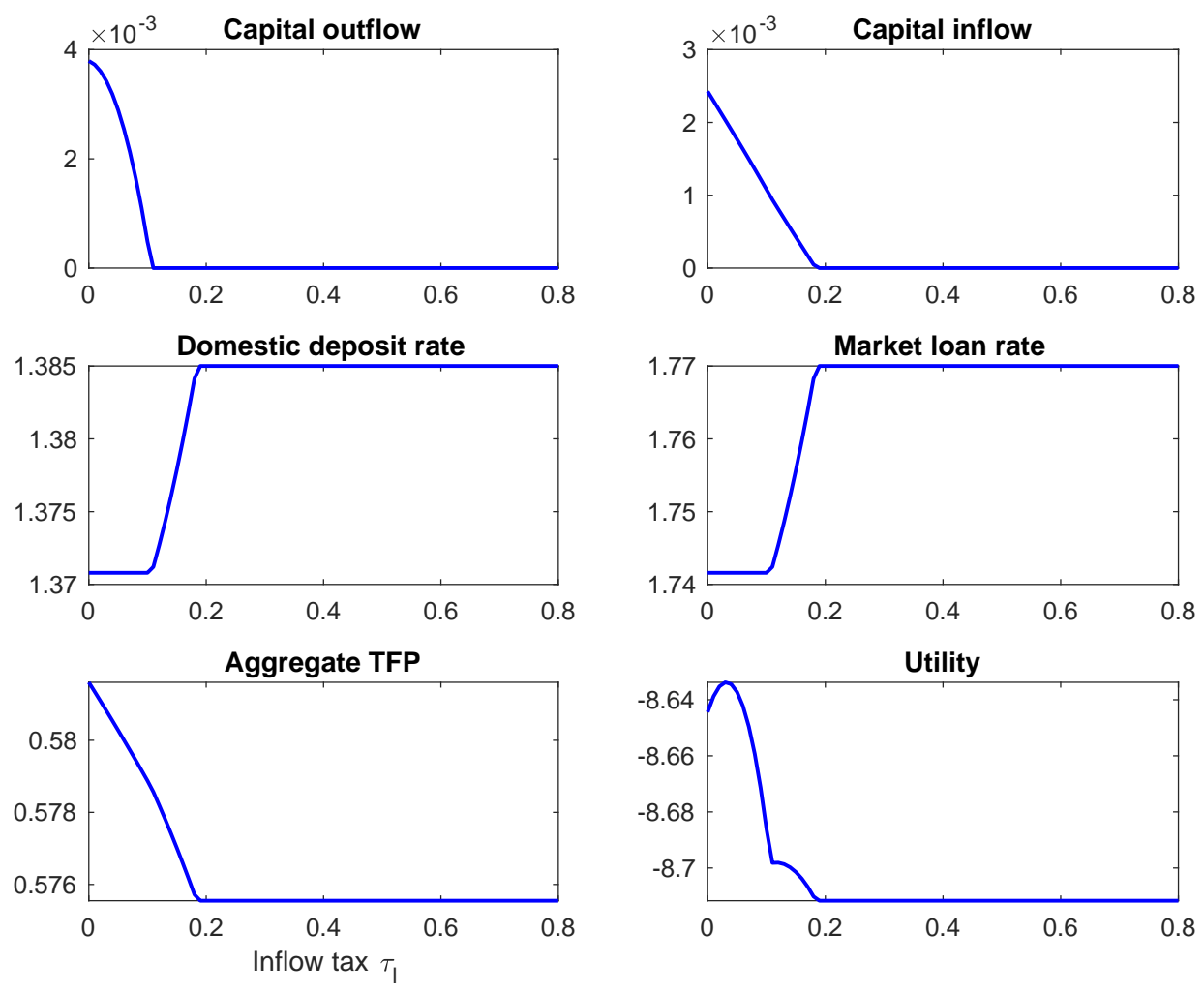

FigurE 4. Steady-state implications of a one-way liberalization of capital inflow controls in the benchmark model. 
OPTIMAL CAPITAL ACCOUNT LIBERALIZATION IN CHINA
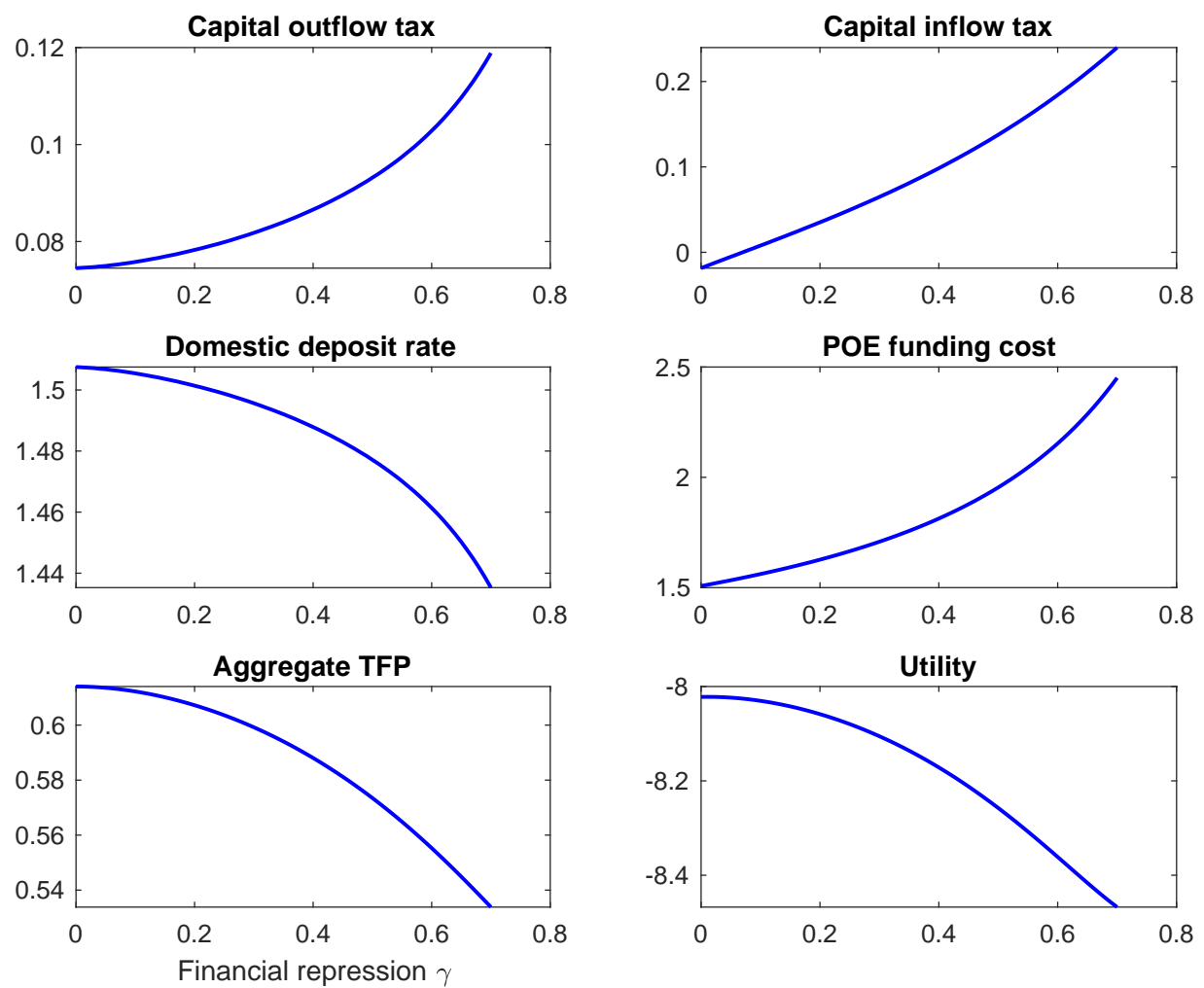

FiguRE 5. Optimal capital control policies under different degree of financial repression $\gamma$ in the benchmark model. 


\section{Appendix A. Steady state AnAlysis And PROOFs of PROPOSitions}

We derive the steady-state results summarized in Section VI and provide proofs of Propositions IV.1 and IV.3.

A.1. Derivation of the SOE funding cost $R_{s}$ and relative size $S\left(\tau_{d}, \tau_{l}, \gamma\right)$. In what follows, we derive the expressions for the effective funding cost for SOEs $\left(R_{s}\right)$ and the relative size of the SOE sector, measured by the share of capital (or equivalently, labor) used by SOEs $S\left(\tau_{d}, \tau_{l}, \gamma\right)$.

We first derive the expression for $R_{s}$. In particular, we rewrite Equation (29) as follows,

$$
R_{s}=\frac{B_{g}+R_{l}\left(B_{s}-B_{g}\right)}{B_{s}}=\frac{\frac{B_{g}}{Y}+R_{l}\left(\frac{B_{s}}{Y}-\frac{B_{g}}{Y}\right)}{\frac{B_{s}}{Y}} .
$$

where $R_{l}$ is given by Eq. (28). The following expressions solve for $\frac{B_{s}}{Y}$ and $\frac{B_{g}}{Y}$ as a function of $R_{s}$ :

$$
\begin{aligned}
\frac{B_{f l}}{Y} & =b_{f}=\kappa_{f}+\frac{1}{\Phi_{b}} \ln \left[\frac{\left(1-\tau_{l}\right) R_{l}}{R^{*}}\right] \\
\frac{B_{s}}{Y} & =\frac{w H_{s}+r^{k} K_{s}}{p_{s} Y_{s}} \frac{p_{s} Y_{s}}{Y}=\frac{1}{R_{s}} \phi \\
\frac{B_{p}}{Y} & =\frac{w H_{p}+r^{k} K_{p}}{p_{p} Y_{p}} \frac{p_{p} Y_{p}}{Y}=\frac{1}{R_{p}}(1-\phi)=\frac{1}{R_{l}}(1-\phi), \\
\frac{D}{Y} & =\frac{B_{s}}{Y}+\frac{B_{p}}{Y}-\frac{B_{f l}}{Y}=\frac{1}{R_{s}} \phi+\frac{1}{R_{l}}(1-\phi)-b_{f}, \\
\frac{B_{g}}{Y} & =\gamma \frac{D}{Y}=\gamma\left(\frac{\phi}{R_{s}}+\frac{1-\phi}{R_{l}}-b_{f}\right) .
\end{aligned}
$$

Substituting the above equations into Eq. (46) gives,

$$
R_{s}=\frac{\gamma\left(\frac{\phi}{R_{s}}+\frac{1-\phi}{R_{l}}-b_{f}\right)+R_{l}\left[\frac{\phi}{R_{s}}-\gamma\left(\frac{\phi}{R_{s}}+\frac{1-\phi}{R_{l}}-b_{f}\right)\right]}{\frac{\phi}{R_{s}}} .
$$

Note that the only unknown variable in the above equation is $R_{s}$. As a result, we can solve for $R_{s}$ based on Eq. (52), which gives:

$$
R_{s}=\frac{\phi R}{\phi+\left(R_{l}-1\right) \gamma\left(\frac{1-\phi}{R_{l}}-\frac{B_{f l}}{Y}\right)}
$$


We now derive the expression for $S\left(\tau_{d}, \tau_{l}, \gamma\right)$. In particular, we substitute Eq. (28), Eq. (53) and $R_{p}=R_{l}$ into Equation (27) to derive Equation (30),

$$
\begin{aligned}
S\left(\tau_{d}, \tau_{l}, \gamma\right)=\frac{K_{s}}{K_{p}}=\frac{H_{s}}{H_{p}} & =\frac{R_{p}}{R_{s}} \frac{\phi}{1-\phi}=\frac{R_{l}}{R_{s}} \frac{\phi}{1-\phi}, \\
& =\frac{\phi R_{l}+\left(R_{l}-1\right) \gamma R_{l}\left(\frac{1-\phi}{R_{l}}-b_{f}\right)}{\phi R} \frac{\phi}{1-\phi}, \\
& =\left[1+\frac{\phi\left(R_{l}-R\right)+\left(R_{l}-1\right) \gamma(1-\phi)-\left(R_{l}-1\right) \gamma R_{l} b_{f}}{\phi R}\right] \frac{\phi}{1-\phi}, \\
& =\left[1+\frac{\frac{\gamma(R-1)}{1-\gamma}(\phi+1-\phi)-\frac{R-1}{1-\gamma} R_{l} \gamma b_{f}}{\phi}\right] \frac{\phi}{1-\phi}, \\
& =\left[1+\frac{R-1}{R} \frac{\gamma}{1-\gamma} \frac{1}{\phi}\left(1-R_{l} b_{f}\right)\right] \frac{\phi}{1-\phi} .
\end{aligned}
$$

where $b_{f}$ is the ratio of capital inflows to output, given by Eq. (26).

\section{A.2. Proof for Proposition IV.1.}

Proof. For convenience of references, we rewrite Equation (31), which gives the first derivative of $S\left(\tau_{d}, \tau_{l}, \gamma\right)$ with respect to $\tau_{d}$,

$$
\frac{\partial S}{\partial \tau_{d}}=-\frac{R^{*}}{R} \frac{\gamma}{1-\gamma} \frac{1}{1-\phi} \frac{D}{Y}+\frac{R-1}{R} \frac{\gamma}{1-\gamma} \frac{R^{*}}{1-\phi}\left(\frac{1}{1-\gamma} b_{f}+\frac{1}{\Phi_{b}} \frac{1}{R-\gamma}\right)
$$

where $\frac{D}{Y}=\frac{1}{R}\left(1-R_{l} b_{f}\right)>0$ is the domestic deposit-to-output ratio.

We decompose $\frac{\partial S}{\partial \tau_{d}}$ into two parts:

$$
\frac{\partial S}{\partial \tau_{d}}=-h_{1}\left(\tau_{d}\right)+h_{2}\left(\tau_{d}\right)
$$

where

$$
\begin{aligned}
& h_{1}\left(\tau_{d}\right)=\frac{R^{*}}{R^{2}} \frac{\gamma}{1-\gamma} \frac{1}{1-\phi}\left(1-R_{l} b_{f}\right)=\frac{R^{*}}{R} \frac{\gamma}{1-\gamma} \frac{1}{1-\phi} \frac{D}{Y}>0, \\
& h_{2}\left(\tau_{d}\right)=\frac{R-1}{R} \frac{\gamma}{1-\gamma} \frac{R^{*}}{1-\phi}\left(\frac{1}{1-\gamma} b_{f}+\frac{1}{\Phi_{b}} \frac{1}{R-\gamma}\right)>0 .
\end{aligned}
$$

where $b_{f}=\kappa_{f}+\frac{1}{\Phi_{b}} \ln \left[\frac{\left(1-\tau_{l}\right) R_{l}}{R^{*}}\right]$ is the capital inflow to output ratio, and $R_{l}=$ $\frac{\left(1-\tau_{d}\right) R^{*}-\gamma}{1-\gamma}$ is the market loan rate. The follows immediately that both $b_{f}$ and $R_{l}$ decreases with $\tau_{d}$. 
Then we have,

$h_{1}^{\prime}\left(\tau_{d}\right)=\frac{2 R^{* 2}}{R^{3}} \frac{\gamma}{1-\gamma} \frac{1}{1-\phi}\left(1-R_{l} b_{f}\right)+\frac{R^{* 2}}{R^{2}} \frac{\gamma}{1-\gamma} \frac{1}{1-\phi}\left(\frac{1}{1-\gamma} b_{f}+\frac{1}{1-\gamma} \frac{1}{\Phi_{b}}\right)>0$,

$h_{2}^{\prime}\left(\tau_{d}\right)=-\frac{R^{* 2}}{R^{2}} \frac{\gamma}{1-\gamma} \frac{1}{1-\phi}\left(\frac{1}{1-\gamma} b_{f}+\frac{1}{1-\gamma} \frac{1}{\Phi_{b}}\right)-R^{* 2} \frac{(R-1)^{2}}{R} \frac{\gamma}{(1-\gamma)^{2}} \frac{1}{1-\phi} \frac{1}{(R-\gamma)^{2}} \frac{1}{\Phi_{b}}<0$,

if $\quad \tau_{d}=1-\frac{1}{R^{*}}, \quad$ then $\quad R=1, \quad h_{1}\left(\tau_{d}\right)>0, \quad$ and $\quad h_{2}\left(\tau_{d}\right)=0$,

if $\quad \tau_{d} \rightarrow \underline{\tau}_{d} \quad$ such $\quad$ that $1-\frac{\left(1-\underline{\tau}_{d}\right) R^{*}-\gamma}{1-\gamma}\left[\kappa_{b f}+\frac{1}{\Phi_{b}} \ln \left(\frac{\left(1-\tau_{l}\right) \frac{\left(1-\underline{\tau}_{d}\right) R^{*}-\gamma}{1-\gamma}}{R^{*}}\right)\right]=0$,

then $h_{1}\left(\tau_{d}\right) \rightarrow 0$, and $h_{2}\left(\tau_{d}\right)>0$.

It follows from the Mean-Value Theorem that, for given values of $\tau_{l}$ and $\gamma$, there exists a threshold value of $\bar{\tau}_{d} \in\left(-\infty, 1-\frac{1}{R^{*}}\right)$, such that $h_{1}\left(\tau_{d}\right)=h_{2}\left(\tau_{d}\right)$. Furthermore,

$$
\begin{aligned}
& \frac{\partial S}{\partial \tau_{d}} \geq-h_{1}\left(\bar{\tau}_{d}\right)+h_{2}\left(\bar{\tau}_{d}\right)=0, \quad \text { if } \quad \tau_{d} \leq \bar{\tau}_{d}, \\
& \frac{\partial S}{\partial \tau_{d}}<-h_{1}\left(\bar{\tau}_{d}\right)+h_{2}\left(\bar{\tau}_{d}\right)=0 .
\end{aligned}
$$

\section{A.3. Proof for Proposition IV.3.}

Proof. For convenience of references, we rewrite Equation (33), which gives the first derivative of $S\left(\tau_{d}, \tau_{l}, \gamma\right)$ with respect to $\gamma$, as follows,

$$
\begin{aligned}
\frac{\partial S}{\partial \gamma} & =(R-1) \frac{1}{1-\phi} \frac{1}{(1-\gamma)^{2}} \frac{D}{Y}-\frac{R-1}{R} \frac{\gamma}{1-\gamma} \frac{1}{1-\phi} \frac{R-1}{(1-\gamma)^{2}}\left(b_{f}+\frac{1}{\Phi_{b}}\right) \\
& =\frac{R-1}{R} \frac{1}{1-\phi} \frac{1}{(1-\gamma)^{2}} g\left(\tau_{d}, \tau_{l}, \gamma\right)
\end{aligned}
$$

where $\frac{D}{Y}=\frac{1}{R}\left(1-R_{l} b_{f}\right)$ is the deposit-to-output ratio. $b_{f}=\kappa_{f}+\frac{1}{\Phi_{b}} \ln \left[\frac{\left(1-\tau_{l}\right) R_{l}}{R^{*}}\right]$ is the capital inflow to output ratio, and $R_{l}=\frac{\left(1-\tau_{d}\right) R^{*}-\gamma}{1-\gamma}$ is the market loan rate. And $g\left(\tau_{d}, \tau_{l}, \gamma\right)$ is given by,

$$
\begin{aligned}
g\left(\tau_{d}, \tau_{l}, \gamma\right) & =1-R_{l} b_{f}-\frac{\gamma}{1-\gamma}(R-1)\left(b_{f}+\frac{1}{\Phi_{b}}\right) \\
& =1-\frac{\left(1-\tau_{d}\right) R^{*}-\gamma}{1-\gamma}\left[\kappa_{f}+\frac{1}{\Phi_{b}} \ln \left(\frac{\left(1-\tau_{l}\right) \frac{\left(1-\tau_{d}\right) R^{*}-\gamma}{1-\gamma}}{R^{*}}\right)\right] \\
& -\frac{\gamma}{1-\gamma}\left(\left(1-\tau_{d}\right) R^{*}-1\right)\left(\left[\kappa_{f}+\frac{1}{\Phi_{b}} \ln \left(\frac{\left(1-\tau_{l}\right) \frac{\left(1-\tau_{d}\right) R^{*}-\gamma}{1-\gamma}}{R^{*}}\right)\right]+\frac{1}{\Phi_{b}}\right) .
\end{aligned}
$$


Then we have that.

$$
\begin{aligned}
& \frac{\partial g}{\partial \gamma}=-\frac{R-1}{(1-\gamma)^{2}}\left(b_{f}+\frac{1}{\Phi_{b}}\right)-\frac{1}{(1-\gamma)^{2}}(R-1)\left(b_{f}+\frac{1}{\Phi_{b}}\right)-\frac{\gamma}{1-\gamma} \frac{1}{\Phi_{b}} \frac{(R-1)^{2}}{(R-\gamma)(1-\gamma)}<0, \\
& \text { if } \quad \gamma=0, g\left(\tau_{d}, \tau_{l}, \gamma\right)=1-R_{l} b_{f}=R \frac{D}{Y}>0, \\
& \text { if } \quad \gamma=1, g\left(\tau_{d}, \tau_{l}, \gamma\right)=-\infty .
\end{aligned}
$$

Therefore, with the Mean Value Theorem, there exists $\bar{\gamma} \in(0,1)$ such that, if $\gamma \leq \bar{\gamma}$, then $g\left(\tau_{d}, \tau_{l}, \gamma\right) \geq 0$ and therefore $\frac{\partial S}{\partial \gamma} \geq 0$; if $\gamma>\bar{\gamma}$, then $g\left(\tau_{d}, \tau_{l}, \gamma\right)<0$ and therefore $\frac{\partial S}{\partial \gamma}<0$. 